\title{
2. OLIGOCENE AND EARLY MIDDLE MIOCENE DIATOM BIOSTRATIGRAPHY OF HOLE 884B ${ }^{1}$
}

\author{
Andrey Y. Gladenkov² and John A. Barron ${ }^{3}$
}

\begin{abstract}
An Oligocene through early Miocene diatom zonation is proposed for the North Pacific based on the stratigraphic documentation and illustration of diatom taxa from Hole 884B on the eastern flank of Detroit Seamount in the northwest Pacific. The Hole $884 \mathrm{~B}$ section is unique in the North Pacific because it contains a nearly continuous record of diatom sedimentation covering the last 30 m.y. Paleomagnetic stratigraphy is available for the last 19-20 m.y. of that record.

The successive FOs of Rocella vigilans ( $\sim 30.2 \mathrm{Ma})$, Cavitatus rectus ( $29.6 \mathrm{Ma})$, Rocella gelida ( $28.3 \mathrm{Ma})$, Thalassiosira praefraga sp. nov. ( 24.0 Ma), Thalassiosira fraga (20.3 Ma), Crucidenticula sawamurae (18.4 Ma), and Crucidenticula kanayae $(16.9 \mathrm{Ma})$ are the basis for proposing partial range zones with the same successive names. The Denticulopsis praelauta, $D$. lauta, and $D$. hyalina zones are recognized in the overlying lower middle Miocene sediments in Hole 884B. One new species, Thalassiosira praefraga A. Gladenkov et Barron sp. nov., is proposed.
\end{abstract}

\section{INTRODUCTION}

Although the late early Miocene to Quaternary diatom biostratigraphy of the North Pacific region is well known (Schrader, 1973; Koizumi, 1985; Barron, 1985b, 1992; Akiba, 1986), studies of the Oligocene and the early part of the early Miocene have been largely confined to isolated samples and/or sections bounded either by unconformities or intervals barren of diatoms. Limited late Oligocene and early Miocene diatom assemblages have been documented from Deep Sea Drilling Project (DSDP) Sites 438 and 439 off the northeast coast of Japan (late early Miocene) by Barron (1980), Akiba (1986), Akiba and Yanagisawa (1986), and Yanagisawa and Akiba (1990); from a calcareous nodule from the Okuyama Formation on the Boso Peninsula of central Honshu, Japan (late early Miocene) by Akiba (1980); from the Okubosawa section of eastern Hokkaido, Japan (late Oligocene and early Miocene) by Akiba et al. (1993); from isolated dredge haul samples from the Navarin Basin of the Bering Sea (late Oligocene? and earliest Miocene) by Baldauf and Barron (1987); from the San Gregorio Formation of southern Baja California, Mexico (late Oligocene and earliest Miocene) by Kim and Barron (1986); and from the Morowan Formation of eastern Hokkaido (early late Oligocene) by Saito et al. (1988). Slightly older early Oligocene diatom assemblages are reported from the Shirasaka Formation in the Joban Coal Field of northeast Japan by Yanagisawa and Suzuki (1987) and from the Kamensky Formation of Bering Island in the Komandorsky Islands at the westernmost end of the Aleutians by Gladenkov (1988). Additional Oligocene assemblages are documented in Russian literature from the Viventekskaya and Gakhinskaya formations of western Kamchatka by Dolmatova et al. (1984), from Karaginsky Island off northeastern Kamchatka by Oreshkina (1982), from Sakhalin Island by Tuzov et al. (1991), as well as from dredge samples taken from the seafloor off the Kuril Islands (Pushkar, 1987) and off eastern Kamchatka (Gleser et al., 1986).

In spite of these numerous studies, the diatom biostratigraphy of the upper Oligocene and the greater part of the lower Miocene age

\footnotetext{
${ }^{1}$ Rea, D.K., Basov, 1.A., Scholl, D.W., and Allan, J.F. (Eds.), 1995. Proc. ODP, Sci. Results, 145: College Station, TX (Ocean Drilling Program).

${ }^{2}$ Institute of the Lithosphere, Russian Academy of Sciences, Staromonetny Per. 22. Moscow 109180, Russian Federation.

${ }^{3}$ U.S. Geological Survey (MS 915), 345 Middlefield Road, Menlo Park, CA 94025, U.S.A.
}

sediments of the North Pacific is largely uncertain (Barron, 1985b; Fenner, 1985; Akiba et al., 1993) because of the absence of continuous sections and the lack of good correlations to the geological time scale. Consequently, when a seemingly complete section of upper Oligocene through lower Miocene diatom-bearing sediment was cored in Ocean Drilling Program (ODP) Hole 884B (Cores 145884B-63X through -70X) (Shipboard Scientific Party, 1993b) (Fig. 1 ) in the northwest Pacific on the eastern flank of Detroit Seamount $\left(51^{\circ} 27.026^{\prime} \mathrm{N}, 168^{\circ} 20.228^{\prime} \mathrm{E}\right.$, water depth $\left.3827 \mathrm{~m}\right)$, a unique opportunity presented itself to clarify the upper Oligocene and lower Miocene diatom biostratigraphy in the North Pacific. A detailed study of this material was initiated by A. Gladenkov with this goal in mind.

\section{MATERIALS AND METHODS}

Samples were selected for study from the FO of Denticulopsis hyalina in Sample 145-884B-62X-4, 25-26 cm, through the base of the diatom-bearing sediments in Core 145-884B-74X. Generally, one sample per section was taken for study from near the $25 \mathrm{~cm}$ interval of each section. Diatoms are present throughout this interval but with varying abundance and preservation.

Aboard the JOIDES Resolution, strewn slides were prepared by placing a small amount of material in a snap-cap vial, adding distilled water, agitating the vial, and removing part of the upper suspension with a pipette. When required (because of a low concentration of diatoms or an induration of the sediment), selected samples were processed by boiling them in hydrogen peroxide and hydrochloric acid, then using the centrifuge (at $1200 \mathrm{rpm}$ for $2-4 \mathrm{~min}$ ) to remove these chemicals from the suspension. On land in the laboratory, beakers were used in the preparation of additional samples in the place of the snap-cap vials, and acid-treated material was made $\mathrm{pH}$ neutral by repeated washing with distilled water, allowing $4 \mathrm{hr}$ or more for settling. Strewn slides were prepared by spreading the pipette suspension onto a cover glass (size $22 \times 30 \mathrm{~mm}$ ), drying on a hot plate, and mounting in Hyrax (index of diffraction =1.71). A single slide per sample was examined under a Jeneval (Zeiss) light microscope by A. Gladenkov at $\times 400$ with identifications checked at $\times 1000$. J.A. Barron checked occurrences on a second set of slides. Whenever possible, all of the diatom taxa were tabulated until 200 specimens (other than Chaetoceros spores) were counted. Then, the rest of the slide was examined in its entirety for sparser occurrences. When fewer than 200 diatom valves were encountered on a slide, all of the taxa were tabulated.

Absolute ages are updated throughout this paper according to the Cande and Kent (1992) geomagnetic polarity time scale. The correla- 
Table 1. Relative abundance of common and stratigraphically important diatoms in the Oligocene to lower middle Miocene section of Hole 884B compared with occurence of diatom zones.

\begin{tabular}{|c|c|c|c|c|c|c|c|c|c|c|c|c|c|c|c|c|c|c|c|c|c|c|c|c|c|}
\hline $\begin{array}{l}\text { Core, section. } \\
\text { interval }(\mathrm{cm})\end{array}$ & $\begin{array}{l}\text { Depth } \\
\text { (mbst) }\end{array}$ & Zone & 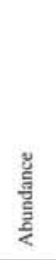 & 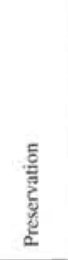 & 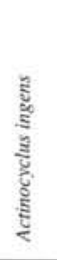 & 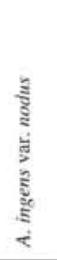 & 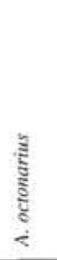 & है & 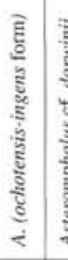 & 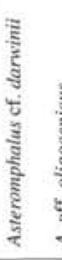 & 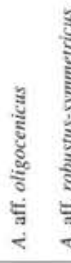 & 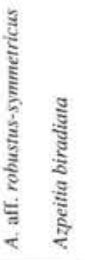 & 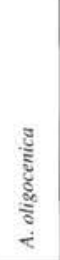 & 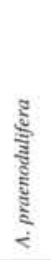 & 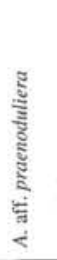 & है & 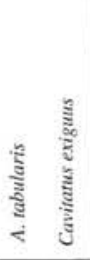 & 仓ू & 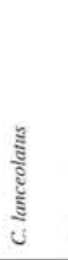 & 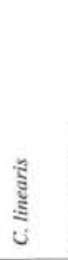 & 竎 & 气ूँ & 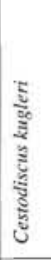 & 气 & 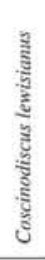 \\
\hline $\begin{array}{l}145-884 \mathrm{~B}- \\
62 \mathrm{X}-4,25-26\end{array}$ & 570.05 & D. hyalina & C-A & $\mathrm{G}-\mathrm{M}$ & 90 & 5 & + & & & & & & & & & & 1 & 6 & 7 & $(+)$ & 4 & & & & \\
\hline $\begin{array}{l}62 X-6,25-26 \\
62 X-C C \\
63 X-2,25-26\end{array}$ & $\begin{array}{l}573.05 \\
574.21 \\
576.55 \\
\end{array}$ & D. lauta & $\begin{array}{l}\mathrm{A} \\
\mathrm{A} \\
\mathrm{A}\end{array}$ & $\begin{array}{l}\mathrm{G} \\
\mathrm{G} \\
\mathrm{G}\end{array}$ & $\begin{array}{r}118 \\
134 \\
96 \\
\end{array}$ & $\begin{array}{r}5 \\
8 \\
+ \\
\end{array}$ & + & & & & & & & & & & $\begin{array}{l}+ \\
+ \\
1 \\
\end{array}$ & $\begin{array}{l}3 \\
3 \\
1 \\
\end{array}$ & $\begin{array}{l}1 \\
+\end{array}$ & + & $\begin{array}{l}2 \\
3 \\
6 \\
\end{array}$ & & & & 1 \\
\hline $\begin{array}{l}63 X-4,25-26 \\
63 X-5,25-26 \\
63 X-6,25-26 \\
63 X-C C\end{array}$ & $\begin{array}{l}579.55 \\
581.05 \\
58.55 \\
583.83 \\
\end{array}$ & $\begin{array}{c}D \\
\text { praeiauta }\end{array}$ & $\begin{array}{l}\text { C } \\
\text { A } \\
\text { A } \\
\text { A }\end{array}$ & $\begin{array}{c}M \\
G \\
G-M \\
G\end{array}$ & $\begin{array}{r}170 \\
30 \\
112 \\
118 \\
\end{array}$ & & & & & + & + & $\begin{array}{l}+ \\
i \\
+\end{array}$ & & & & & $\begin{array}{r}+ \\
+ \\
+\end{array}$ & $\begin{array}{l}+ \\
+ \\
+ \\
1\end{array}$ & & $\begin{array}{l}+ \\
+ \\
+\end{array}$ & $\begin{array}{l}2 \\
6 \\
4 \\
7 \\
\end{array}$ & & & & $\begin{array}{l}+ \\
+\end{array}$ \\
\hline $\begin{array}{l}64 X-1,25-26 \\
64 X-2,25-26 \\
64 X-3,25-26 \\
64 X-4,28-29\end{array}$ & $\begin{array}{l}584.65 \\
586.15 \\
58.75 \\
589.15 \\
\end{array}$ & $\begin{array}{c}C r . \\
\text { kanayae }\end{array}$ & $\begin{array}{c}\mathrm{C} \\
\mathrm{C}-\mathrm{A} \\
\mathrm{A} \\
\mathrm{C}-\mathrm{A}\end{array}$ & $\begin{array}{l}\mathrm{G} \\
\mathrm{G} \\
\mathrm{G} \\
\mathrm{G} \\
\end{array}$ & $\begin{array}{r}34 \\
47 \\
14 \\
8 \\
\end{array}$ & & & + & 2 & + & + & $\begin{array}{l}1 \\
1 \\
+ \\
+\end{array}$ & $(+)$ & $\begin{array}{l}\stackrel{(+)}{+} \\
1 \\
1 \\
+ \\
+\end{array}$ & & + & $\begin{array}{l}+ \\
+ \\
1\end{array}$ & $\begin{array}{l}1 \\
+ \\
+ \\
i\end{array}$ & & $\begin{array}{l}+ \\
+ \\
\end{array}$ & $\begin{array}{r}12 \\
14 \\
7 \\
9 \\
\end{array}$ & & & & + \\
\hline $\begin{array}{l}64 X-5,25-26 \\
64 X-6,28-29 \\
64 X-C C \\
65 X-2,25-26 \\
65 X-4,25-26 \\
65 X-6,25-26 \\
65 X-C C\end{array}$ & $\begin{array}{l}590.65 \\
591.48 \\
594.1 \\
595.85 \\
598.85 \\
601.85 \\
603.8\end{array}$ & $\begin{array}{c}C r \\
\text { sawamurae }\end{array}$ & $\begin{array}{l}\text { A } \\
\text { C } \\
\text { A } \\
\text { C } \\
\text { C } \\
\text { C } \\
\text { C }\end{array}$ & $\begin{array}{c}M-G \\
G \\
M \\
M \\
M \\
M \\
M \\
\end{array}$ & $\begin{array}{l}4 \\
6 \\
3 \\
6 \\
7 \\
3 \\
3 \\
\end{array}$ & & $\begin{array}{l}+ \\
+ \\
+ \\
+ \\
\end{array}$ & $\begin{array}{r}2 \\
17 \\
+ \\
+ \\
+ \\
+ \\
3 \\
\end{array}$ & \begin{tabular}{r|}
6 \\
3 \\
2 \\
5 \\
18 \\
6 \\
\end{tabular} & $\begin{array}{l}+ \\
+\end{array}$ & $\begin{array}{l}+ \\
+\end{array}$ & $\begin{array}{l}1 \\
3 \\
2 \\
+ \\
+\end{array}$ & & $\begin{array}{l}+ \\
+ \\
+ \\
+ \\
+\end{array}$ & $\begin{array}{l}+ \\
+ \\
+ \\
+\end{array}$ & & $\begin{array}{l}+ \\
+\end{array}$ & $\begin{array}{l}1 \\
1 \\
+ \\
1 \\
6 \\
4 \\
2 \\
\end{array}$ & & $\begin{array}{l}3 \\
+ \\
+ \\
+ \\
2 \\
+ \\
\end{array}$ & $\begin{array}{r}11 \\
17 \\
13 \\
3 \\
11 \\
5 \\
3 \\
\end{array}$ & & & & $\begin{array}{l}+ \\
+ \\
\end{array}$ \\
\hline $\begin{array}{l}66 \mathrm{X}-1,25-26 \\
66 \mathrm{X}-2,25-26 \\
66 \mathrm{X}-3,25-26 \\
66 \mathrm{X}-4,25-26 \\
66 \mathrm{X}-5,25-26\end{array}$ & $\begin{array}{l}604.05 \\
603.35 \\
605.55 \\
607.05 \\
608.55 \\
\end{array}$ & T. fraga & $\begin{array}{l}\mathrm{A} \\
\mathrm{C} \\
\mathrm{A} \\
\mathrm{F} \\
\mathrm{C} \\
\end{array}$ & $\begin{array}{c}M-G \\
M \\
G \\
M \\
M\end{array}$ & (t) & & $\begin{array}{l}+ \\
3 \\
3 \\
3 \\
5 \\
5\end{array}$ & & & & & 1 & $\begin{array}{l}(+) \\
(+) \\
(4) \\
(3) \\
(+) \\
\end{array}$ & $\begin{array}{l}+ \\
6 \\
7\end{array}$ & $\begin{array}{l}1 \\
3 \\
3\end{array}$ & 1 & & $\begin{array}{r}2 \\
2 \\
10 \\
17 \\
12 \\
\end{array}$ & & $\begin{array}{l}1 \\
6 \\
1 \\
4 \\
\end{array}$ & $\begin{array}{r}4 \\
4 \\
15 \\
3 \\
4 \\
\end{array}$ & & & $\begin{array}{l}+ \\
2 \\
2 \\
\end{array}$ & \\
\hline $\begin{array}{l}66 \mathrm{X}-6,25-26 \\
66 \mathrm{X}-\mathrm{CC} \\
67 \mathrm{X}-1,24-25 \\
67 \mathrm{X}-2,24-25 \\
67 \mathrm{X}-3,24-25 \\
67 \mathrm{X}-4,24-25 \\
67 \mathrm{X}-5,24-25 \\
67 \mathrm{X}-6.24-25 \\
67 \mathrm{X}-7,24-25 \\
67 \mathrm{X}-\mathrm{CC} \\
\end{array}$ & $\begin{array}{l}610.05 \\
612.3 \\
613.54 \\
615.54 \\
616.54 \\
618.54 \\
619.54 \\
62.1 .04 \\
621.68 \\
621.84 \\
\end{array}$ & $\begin{array}{c}T . \\
\text { praefraga }\end{array}$ & $\begin{array}{l}\text { C } \\
\text { F } \\
\text { C } \\
\text { C } \\
\text { C } \\
\text { C } \\
\text { C } \\
\text { C } \\
\text { C } \\
\text { F }\end{array}$ & $\begin{array}{c}\mathrm{M} \\
\mathrm{M} \\
\mathrm{M} \\
\mathrm{M} \\
\mathrm{G} \\
\mathrm{M}-\mathrm{G} \\
\mathrm{M} \\
\mathrm{G} \\
\mathrm{G} \\
\mathrm{M} \\
\end{array}$ & $\begin{array}{l}(+) \\
(+)\end{array}$ & & $\begin{array}{l}6 \\
1 \\
1 \\
1 \\
1 \\
2 \\
2 \\
1 \\
3 \\
2\end{array}$ & & & & & $\begin{array}{c}+ \\
10\end{array}$ & $\begin{array}{l}(+) \\
(1) \\
5 \\
+ \\
+ \\
1 \\
+ \\
+ \\
+\end{array}$ & + & & + & $\begin{array}{l}1 \\
2 \\
5 \\
3 \\
2 \\
4 \\
1 \\
3\end{array}$ & $\begin{array}{r}12 \\
8 \\
4 \\
1 \\
11 \\
3 \\
19 \\
7 \\
5 \\
11 \\
\end{array}$ & & $\begin{array}{r}1 \\
4 \\
1 \\
+ \\
5 \\
3 \\
30 \\
4 \\
+ \\
4 \\
\end{array}$ & $\begin{array}{r}12 \\
19 \\
10 \\
2 \\
14 \\
6 \\
11 \\
3 \\
6 \\
9 \\
\end{array}$ & $\begin{array}{c}(+) \\
+ \\
1 \\
+ \\
1 \\
2 \\
1 \\
1 \\
2 \\
1\end{array}$ & $\begin{array}{l}1 \\
+ \\
+ \\
+ \\
+ \\
+ \\
+ \\
\end{array}$ & $\begin{array}{r}6 \\
10 \\
+ \\
+ \\
+ \\
+ \\
+ \\
+ \\
+\end{array}$ & \\
\hline 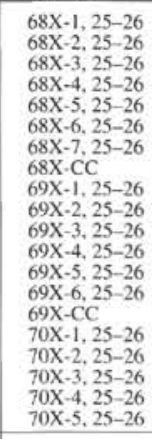 & $\begin{array}{l}623.05 \\
624.55 \\
626.05 \\
627.55 \\
622.05 \\
630.55 \\
632.25 \\
632.24 \\
632.25 \\
634.15 \\
635.65 \\
637.15 \\
638.65 \\
640.15 \\
642.0 \\
642.25 \\
643.75 \\
643.25 \\
64.75 \\
648.25\end{array}$ & $\begin{array}{l}\text { Rocella } \\
\text { gelida }\end{array}$ & $\begin{array}{l}\text { F } \\
\text { R-F } \\
\text { F } \\
\text { F } \\
\text { R } \\
\text { F } \\
\text { F } \\
\text { C } \\
\text { C } \\
\text { C } \\
\text { C } \\
\text { C } \\
\text { R } \\
\text { B } \\
\text { R } \\
\text { B } \\
\text { B } \\
\text { B } \\
\text { B } \\
\text { F }\end{array}$ & $\begin{array}{c}\text { P } \\
P-M \\
M \\
M-M \\
P-M \\
P-M \\
M \\
M \\
M \\
G \\
G \\
G-G \\
M-M \\
M \\
P \\
P \\
P \\
\\
P \\
P\end{array}$ & & & $\begin{array}{l}3 \\
1 \\
1 \\
1 \\
+ \\
3 \\
1 \\
+ \\
+ \\
+\end{array}$ & & & & + & & $\begin{array}{l}1 \\
+\end{array}$ & & & & $\begin{array}{l}2 \\
1 \\
+\end{array}$ & $\begin{array}{r}11 \\
4 \\
20 \\
5 \\
3 \\
6 \\
5 \\
5 \\
19 \\
13 \\
31 \\
45 \\
45 \\
3\end{array}$ & $\begin{array}{l}1 \\
1 \\
1\end{array}$ & $\begin{array}{r}2 \\
1 \\
11 \\
1 \\
1 \\
3 \\
+ \\
2 \\
2 \\
6 \\
11 \\
9 \\
18 \\
1 \\
(1)\end{array}$ & $\begin{array}{r}8 \\
3 \\
5 \\
9 \\
9 \\
3 \\
6 \\
5 \\
13 \\
5 \\
13 \\
31 \\
21 \\
2 \\
\text { (1) }\end{array}$ & $\begin{array}{r}10 \\
2 \\
1 \\
1 \\
1 \\
1 \\
2 \\
5 \\
5\end{array}$ & $\begin{array}{l}1 \\
1 \\
1 \\
1 \\
\\
+ \\
+ \\
1 \\
1\end{array}$ & $\begin{array}{l}1 \\
\\
+ \\
+ \\
+ \\
+\end{array}$ & \\
\hline $\begin{array}{l}70 X-6,25-26 \\
70 X-7,25-26 \\
70 X-c c \\
71 X-1,25-26 \\
71 X-3,25-26 \\
71 X-4,25-26\end{array}$ & $\begin{array}{l}649.75 \\
65.25 \\
651.7 \\
651.95 \\
655.95 \\
656.45 \\
\end{array}$ & $\begin{array}{c}\text { Cavitatus } \\
\text { rectus }\end{array}$ & $\begin{array}{l}\mathrm{C} \\
\mathrm{c} \\
\mathrm{C} \\
\mathrm{c} \\
\mathrm{C} \\
\mathrm{C}\end{array}$ & $\begin{array}{l}\mathrm{M} \\
\mathrm{M} \\
\mathrm{M} \\
\mathrm{M} \\
\mathrm{M} \\
\mathrm{M}\end{array}$ & & & $\begin{array}{l}+ \\
1 \\
3 \\
+ \\
1 \\
2 \\
\end{array}$ & & & & & + & $\begin{array}{r}1 \\
+ \\
1 \\
1 \\
+ \\
\end{array}$ & & & & + & $\begin{array}{r}9 \\
56 \\
57 \\
45 \\
57 \\
4 \\
\end{array}$ & & $\begin{array}{l}17 \\
25 \\
38 \\
29 \\
30\end{array}$ & $\begin{array}{l}33 \\
14 \\
14 \\
24 \\
17 \\
10 \\
\end{array}$ & $\begin{array}{r}4 \\
15 \\
20 \\
21 \\
2 \\
1 \\
\end{array}$ & $\begin{array}{l}+ \\
1 \\
4 \\
2 \\
3 \\
7 \\
\end{array}$ & $\begin{array}{l}+ \\
+ \\
4 \\
+ \\
+ \\
1\end{array}$ & \\
\hline $\begin{array}{l}71 X-5,25-26 \\
71 X-6,25-26 \\
71 X-7,25-26 \\
\end{array}$ & $\begin{array}{l}657.95 \\
659.45 \\
660.95 \\
\end{array}$ & R. vigilans & $\begin{array}{l}\mathrm{C} \\
\mathrm{F} \\
\mathrm{R} \\
\end{array}$ & $\begin{array}{l}\mathrm{M} \\
\mathrm{M} \\
\mathrm{M}\end{array}$ & & & $\begin{array}{l}4 \\
2 \\
1 \\
\end{array}$ & & & & & & $\begin{array}{l}+ \\
2\end{array}$ & & & & 2 & $\begin{array}{l}2 \\
5 \\
2 \\
\end{array}$ & & & $\begin{array}{l}3 \\
6 \\
4\end{array}$ & & $\begin{array}{c}92 \\
3\end{array}$ & 4 & \\
\hline $\begin{array}{l}71 X-C C \\
72 X-C C \\
73 X-C C \\
74 X-C C\end{array}$ & $\begin{array}{l}661.3 \\
671.0 \\
678.02 \\
690.2\end{array}$ & Unzoned & $\begin{array}{l}\mathrm{R} \\
\mathrm{R} \\
\mathrm{R} \\
\mathrm{R}\end{array}$ & $\begin{array}{l}\mathrm{M} \\
\mathrm{P} \\
\mathrm{P} \\
\mathrm{M}\end{array}$ & & & 3 & & & & & & i & & & & $\frac{2}{3}$ & 1 & & & 4 & & & & \\
\hline
\end{tabular}

Notes: Relative abundance $(\mathrm{A}=$ abundant, $\mathrm{C}=$ common, $\mathrm{F}=$ few, $\mathrm{R}=$ rare, $\mathrm{B}=$ barren $)$ and preservation $(\mathrm{G}=$ good, $\mathrm{M}=$ moderate, $\mathrm{P}=$ poor $)$ of each sample are also estimated. Plus sign $(+)=$ specimens recorded after count. Parentheses are placed around occurrences of specimens with uncertain identification (e.g., fragments and related taxonomic forms). $N=$ number

tion of the geologic epochs and periods used follows that of Berggren et al. (1985a, 1985b).

\section{RESULTS}

The tabulated occurrences of stratigraphically important and relatively common diatom taxa are shown in Table 1 . The North Pacific references on Oligocene and early Miocene diatom assemblages were consulted in choosing stratigraphically important taxa, along with Fenner (1985), Barron (1985a), and Harwood and Maruyama (1992). Numerous other taxa, including Pyxidicula spp., certain Hemiaulus spp., and various benthic taxa were also tabulated; however, they are not treated below the genus level because of time and space limitations. Illustrations of the stratigraphically important and common 
Table 1 (continued).

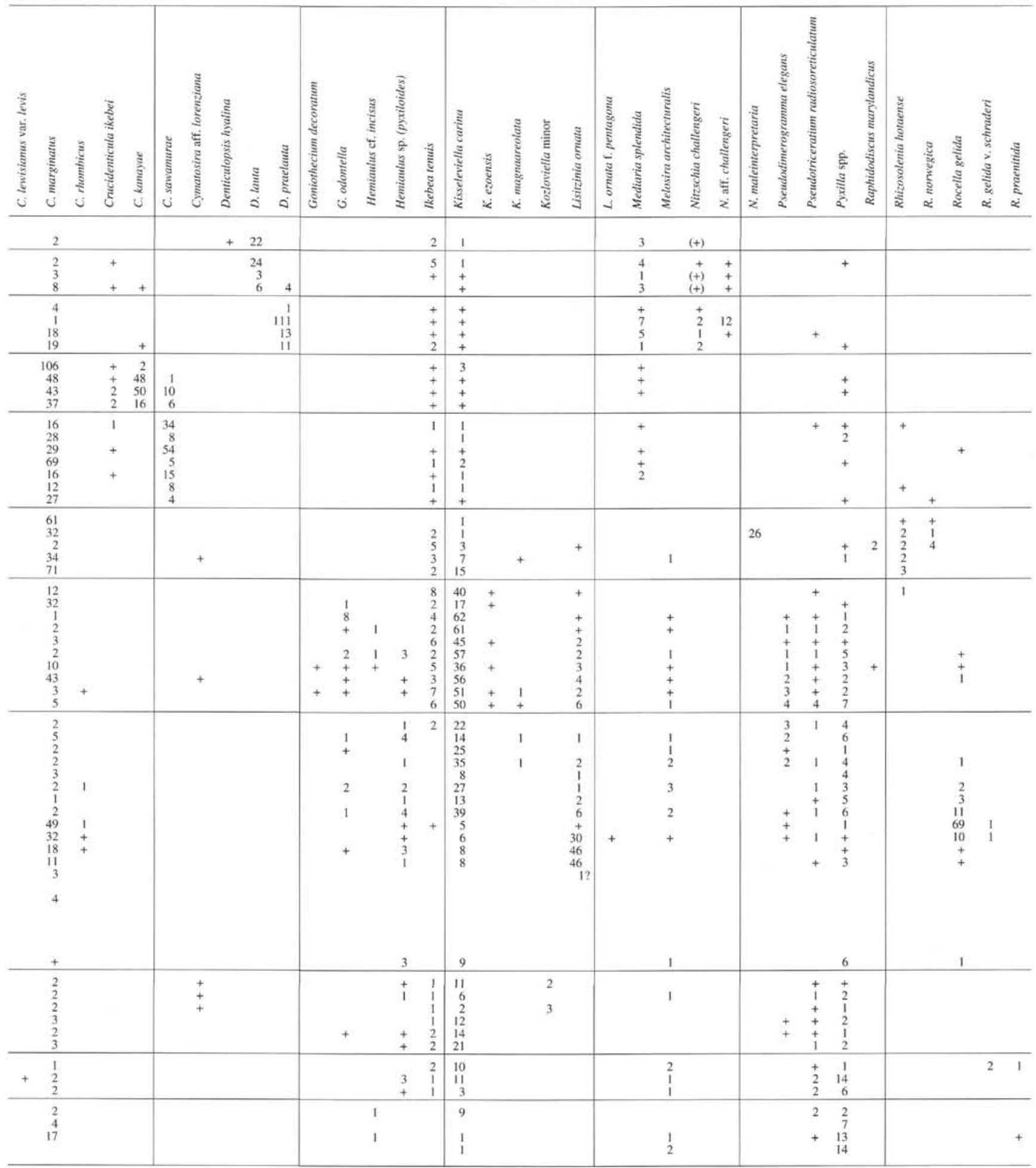

diatom taxa can be found on the plates, and the taxonomy used is summarized in the Appendix.

\section{Preservation}

Diatom preservation is generally moderate to good throughout the section studied (Table 1), with the exception of a barren to poorly preserved interval from the upper part of Core 145-884B-70X to the lower part of Core 145-884B-69X ( 648-638 mbsf) and a poorly preserved interval below 660 mbsf (Core 145-884B-71X).

The ranges of the stratigraphically important diatom taxa in Cores 145-884B-74X through -63X are compiled in Figure 2. Additional warm-water, stratigraphically important taxa such as Coscinodiscus lewisianus, C. lewisianus var. levis, C. rhombicus, Nitzschia maleinterpretaria, and Raphidodiscus marylandicus have very restricted occurrences in Hole 884B (Table 1), most likely during intervals of 
Table 1 (continued).

\begin{tabular}{|c|c|c|c|c|c|c|c|c|c|c|c|c|c|c|c|c|c|c|c|c|c|c|c|c|c|c|c|}
\hline $\begin{array}{l}\text { Core, section, } \\
\text { interval }(\mathrm{cm})\end{array}$ & $\begin{array}{c}\text { Depth } \\
\text { (mbsf) }\end{array}$ & Zone & 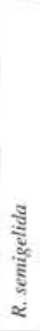 & 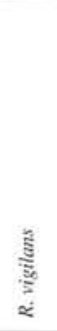 & 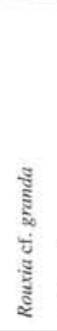 & 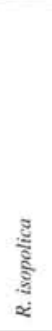 & 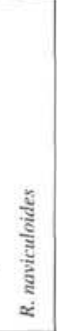 & $\begin{array}{l}\text { हु } \\
\text { ชै } \\
\varkappa\end{array}$ & 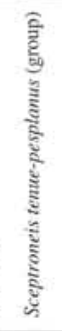 & $\begin{array}{l}\text { है } \\
\text { है } \\
\text { है } \\
\text { है } \\
\text { है } \\
\text { है }\end{array}$ & 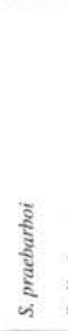 & 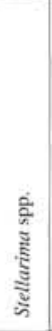 & 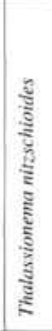 & 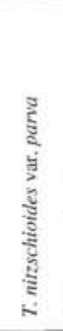 & 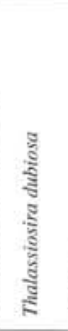 & है & 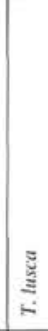 & हूँ & है & 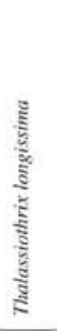 & हैँ & 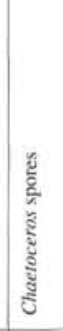 & 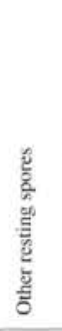 & है & $\begin{array}{l}\text { हूँ } \\
\text { जूँ } \\
\text { हूँ } \\
\text { है }\end{array}$ & 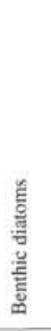 & 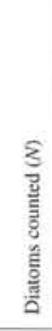 \\
\hline $\begin{array}{l}\begin{array}{r}145-884 \mathrm{~B}- \\
62 \mathrm{X}-4,25-26\end{array}\end{array}$ & 570.05 & D. hyalina & & & & & 1 & & & & 5 & 1 & 3 & & & & & & & 23 & + & 15 & 4 & 3 & + & + & 215 \\
\hline $\begin{array}{l}62 X-6,25-26 \\
62 X-C C \\
63 X-2,25-26\end{array}$ & $\begin{array}{l}573.05 \\
57.21 \\
576.55 \\
\end{array}$ & D. lauta & & & & + & + & & & & $\begin{array}{r}6 \\
3 \\
21 \\
\end{array}$ & $\begin{array}{l}+ \\
+ \\
+\end{array}$ & $\begin{array}{r}3 \\
15 \\
6 \\
\end{array}$ & & & & & & & $\begin{array}{l}18 \\
16 \\
26 \\
\end{array}$ & + & \begin{tabular}{|r}
22 \\
6 \\
5 \\
\end{tabular} & $\begin{array}{l}1 \\
+ \\
+\end{array}$ & $\begin{array}{r}2 \\
+ \\
18 \\
\end{array}$ & $\begin{array}{l}+ \\
+ \\
\end{array}$ & $\begin{array}{l}+ \\
+ \\
+ \\
\end{array}$ & $\begin{array}{l}222 \\
206 \\
205 \\
\end{array}$ \\
\hline $\begin{array}{l}63 X-4,25-26 \\
63 X-5,25-26 \\
63 X-6.25-26 \\
63 X-C C\end{array}$ & $\begin{array}{l}579.55 \\
581.05 \\
582.55 \\
583.83 \\
\end{array}$ & $\begin{array}{c}D . \\
\text { praelauta }\end{array}$ & & & & & $\begin{array}{l}+ \\
7 \\
2\end{array}$ & & & & $\begin{array}{r}7 \\
5 \\
10 \\
2 \\
\end{array}$ & $\begin{array}{r}+ \\
+ \\
10 \\
7 \\
7\end{array}$ & $\begin{array}{l}1 \\
1 \\
4 \\
3\end{array}$ & & & + & & & & $\begin{array}{l}13 \\
14 \\
15 \\
13 \\
\end{array}$ & & $\begin{array}{r}3 \\
22 \\
21 \\
26\end{array}$ & $\begin{array}{l}1 \\
+ \\
3 \\
4 \\
\end{array}$ & $\begin{array}{l}2 \\
1 \\
3 \\
5 \\
\end{array}$ & + & $\begin{array}{l}+ \\
+ \\
+ \\
+\end{array}$ & $\begin{array}{l}203 \\
202 \\
221 \\
226 \\
\end{array}$ \\
\hline $\begin{array}{l}64 X-1,25-26 \\
64 X-2,25-26 \\
64 X-3,25-26 \\
64 X-4,28-29\end{array}$ & $\begin{array}{l}584.65 \\
586.15 \\
587.65 \\
589.15\end{array}$ & $\begin{array}{c}C r \\
\text { kanayae }\end{array}$ & & & & & & & & & $\begin{array}{l}2 \\
4 \\
3 \\
\end{array}$ & $\begin{array}{r}2 \\
3 \\
21 \\
29 \\
\end{array}$ & \begin{tabular}{r|}
10 \\
5 \\
4 \\
4
\end{tabular} & 68 & & & & & & $\begin{array}{l}19 \\
16 \\
40 \\
16 \\
\end{array}$ & & $\begin{array}{l}36 \\
15 \\
14 \\
10 \\
\end{array}$ & $\begin{array}{l}2 \\
+ \\
2 \\
5 \\
\end{array}$ & $\begin{array}{l}1 \\
5 \\
+ \\
1 \\
\end{array}$ & $\begin{array}{l}+ \\
1 \\
+ \\
+\end{array}$ & $\begin{array}{l}+ \\
+ \\
+ \\
+\end{array}$ & $\begin{array}{l}236 \\
215 \\
214 \\
210 \\
\end{array}$ \\
\hline $\begin{array}{l}64 X-5,25-26 \\
64 X-6,28-29 \\
64 X-C C \\
65 X-2,25-26 \\
65 X-4,25-26 \\
65 X-6,25-26 \\
65 X-C C\end{array}$ & $\begin{array}{l}590.65 \\
591.48 \\
594.1 \\
595.85 \\
598.85 \\
601.85 \\
603.8 \\
\end{array}$ & $\begin{array}{c}\text { Cr. } \\
\text { sawamurae }\end{array}$ & & & & & $\begin{array}{l}(+) \\
(+) \\
(+)\end{array}$ & & & & $\begin{array}{ll}4 \\
6 \\
4 \\
4 \\
3 \\
2 \\
2 \\
1\end{array}$ & \begin{tabular}{l|}
31 \\
37 \\
29 \\
69 \\
55 \\
110 \\
109 \\
\end{tabular} & $\begin{array}{l}9 \\
2 \\
3 \\
3 \\
7 \\
3 \\
5 \\
\end{array}$ & 11 & & $\begin{array}{r} \\
\\
+ \\
1 \\
+\end{array}$ & & & & $\begin{array}{l}53 \\
62 \\
57 \\
25 \\
42 \\
30 \\
27 \\
\end{array}$ & & $\begin{array}{l}40 \\
21 \\
21 \\
14 \\
13 \\
9 \\
18 \\
\end{array}$ & $\begin{array}{l}5 \\
2 \\
1 \\
1 \\
3 \\
8 \\
5 \\
\end{array}$ & $\begin{array}{l}+ \\
+ \\
+ \\
+ \\
+\end{array}$ & $\begin{array}{l}+ \\
+ \\
+ \\
2 \\
1 \\
1 \\
2\end{array}$ & $\begin{array}{l}+ \\
2 \\
+ \\
+ \\
+ \\
+\end{array}$ & $\begin{array}{l}240 \\
221 \\
221 \\
214 \\
216 \\
209 \\
218 \\
\end{array}$ \\
\hline $\begin{array}{l}66 \mathrm{X}-1,25-26 \\
66 \mathrm{X}-2,25-26 \\
66 \mathrm{X}-3,25-26 \\
66 \mathrm{X}-4,25-26 \\
66 \mathrm{X}-5,25-26\end{array}$ & $\begin{array}{l}604.05 \\
603.35 \\
605.55 \\
607.05 \\
608.55 \\
\end{array}$ & T. fraga & & & & & & & + & & & $\begin{array}{l}91 \\
63 \\
71 \\
66 \\
43 \\
\end{array}$ & $\begin{array}{l}3 \\
9 \\
4 \\
2 \\
2 \\
\end{array}$ & & & $\begin{array}{r}1 \\
4 \\
37 \\
17 \\
4 \\
\end{array}$ & & & $\begin{array}{r}1 \\
4 \\
14 \\
10 \\
8 \\
\end{array}$ & $\begin{array}{r}23 \\
15 \\
8 \\
1 \\
2 \\
\end{array}$ & & $\begin{array}{l}12 \\
16 \\
22 \\
34 \\
69 \\
\end{array}$ & $\begin{array}{r}6 \\
9 \\
3 \\
18 \\
16 \\
\end{array}$ & $\begin{array}{l}+ \\
+ \\
+ \\
+\end{array}$ & $\begin{array}{l}+ \\
+ \\
2 \\
+ \\
\end{array}$ & $\begin{array}{l}+ \\
1 \\
+ \\
+ \\
3\end{array}$ & $\begin{array}{l}212 \\
216 \\
222 \\
234 \\
269 \\
\end{array}$ \\
\hline $\begin{array}{l}66 X-6,25-26 \\
66 X-C C \\
67 X-1,24-25 \\
67 X-2,24-25 \\
67 X-3,24-25 \\
67 X-4,24-25 \\
67 X-5,24-25 \\
67 X-6,24-25 \\
67 X-7,24-25 \\
67 X-C C \\
\end{array}$ & $\begin{array}{l}610.05 \\
612.3 \\
613.54 \\
615.04 \\
616.54 \\
618.04 \\
619.54 \\
62.04 \\
621.68 \\
621.84 \\
\end{array}$ & $\begin{array}{c}T . \\
\text { praefraga }\end{array}$ & & $\begin{array}{l}+ \\
+\end{array}$ & $\begin{array}{l}+ \\
+ \\
+ \\
+ \\
+\end{array}$ & & $\begin{array}{l}\text { (1) } \\
\text { (1) }\end{array}$ & $\begin{array}{l}+ \\
+ \\
+ \\
i \\
+ \\
i\end{array}$ & $\begin{array}{l}(+) \\
\\
+ \\
+ \\
+ \\
+ \\
+ \\
+ \\
+\end{array}$ & + & & $\begin{array}{r}7 \\
24 \\
10 \\
2 \\
19 \\
2 \\
2 \\
1 \\
3 \\
4 \\
\end{array}$ & \begin{tabular}{|r|}
2 \\
7 \\
1 \\
9 \\
6 \\
12 \\
1 \\
7 \\
2 \\
2 \\
\end{tabular} & & & $\begin{array}{l}+ \\
+ \\
+\end{array}$ & $\begin{array}{l}+ \\
+ \\
+ \\
+ \\
\end{array}$ & $\begin{array}{l}(+) \\
(+) \\
(+) \\
(+)\end{array}$ & $\begin{array}{l}+ \\
7 \\
+ \\
+ \\
1 \\
+ \\
+ \\
+ \\
+ \\
1\end{array}$ & $\begin{array}{r}4 \\
4 \\
5 \\
5 \\
17 \\
5 \\
7 \\
3 \\
11 \\
9 \\
\end{array}$ & & \begin{tabular}{|c|}
89 \\
68 \\
122 \\
62 \\
138 \\
63 \\
53 \\
51 \\
82 \\
99 \\
\end{tabular} & $\begin{array}{l}54 \\
28 \\
30 \\
20 \\
12 \\
25 \\
17 \\
18 \\
20 \\
40 \\
\end{array}$ & $\begin{array}{l}+ \\
1 \\
8 \\
8 \\
3 \\
5 \\
9 \\
4 \\
2 \\
6 \\
\end{array}$ & $\begin{array}{r}5 \\
3 \\
2 \\
17 \\
2 \\
14 \\
3 \\
6 \\
9 \\
7 \\
\end{array}$ & $\begin{array}{r}4 \\
1 \\
2 \\
8 \\
5 \\
5 \\
6 \\
8 \\
2 \\
10 \\
\end{array}$ & $\begin{array}{l}289 \\
268 \\
322 \\
262 \\
338 \\
263 \\
253 \\
251 \\
282 \\
299 \\
\end{array}$ \\
\hline $\begin{array}{l}68 X-1,25-26 \\
68 X-2,25-26 \\
68 X-3.25-26 \\
68 X-4,25-26 \\
68 X-5,25-26 \\
68 X-6,25-26 \\
68 X-7,25-26 \\
68 X-C C \\
69 X-1.25-26 \\
69 X-2,25-26 \\
69 X-3,25-26 \\
69 X-4.25-26 \\
69 X-5,25-26 \\
69 X-6,25-26 \\
69 X-C C \\
70 X-1,25-26 \\
70 X-2,25-26 \\
70 X-3,25-26 \\
70 X-4,25-26 \\
70 X-5,25-26\end{array}$ & $\begin{array}{l}622.05 \\
622.55 \\
622.05 \\
627.55 \\
629.05 \\
630.55 \\
632.05 \\
632.4 \\
632.65 \\
632.15 \\
635.65 \\
637.15 \\
638.65 \\
640.15 \\
642.0 \\
642.25 \\
643.25 \\
6454.25 \\
646.75 \\
648.25\end{array}$ & $\begin{array}{l}\text { Rocella } \\
\text { gelida }\end{array}$ & & $\begin{array}{l}+ \\
+ \\
2 \\
4\end{array}$ & 2 & & (1) & $\begin{array}{r}1 \\
1 \\
+ \\
2\end{array}$ & $\begin{array}{l}1 \\
+ \\
+\end{array}$ & & & \begin{tabular}{r|r|}
1 & 12 \\
12 & 3 \\
1 \\
1 \\
3 \\
2 \\
4 \\
3 \\
2
\end{tabular} & $\begin{array}{l}3 \\
2 \\
5 \\
4 \\
1 \\
4 \\
3 \\
+ \\
+ \\
+ \\
+ \\
+\end{array}$ & & & 1 & i & + & & $\begin{array}{r}11 \\
6 \\
18 \\
22 \\
2 \\
16 \\
17 \\
21 \\
9 \\
30 \\
14 \\
5 \\
1 \\
1 \\
1\end{array}$ & & $\begin{array}{l}56 \\
52 \\
31 \\
75 \\
30 \\
21 \\
15 \\
45 \\
21 \\
5 \\
10 \\
27\end{array}$ & $\begin{array}{r}30 \\
30 \\
10 \\
21 \\
6 \\
15 \\
9 \\
30 \\
5 \\
6 \\
2 \\
14 \\
1\end{array}$ & $\begin{array}{l}4 \\
3 \\
1 \\
1 \\
1 \\
1 \\
2 \\
1 \\
2 \\
1 \\
2 \\
3 \\
3\end{array}$ & $\begin{array}{l}8 \\
8 \\
4 \\
5 \\
4 \\
3 \\
4 \\
7 \\
+ \\
6 \\
7\end{array}$ & $\begin{array}{l}5 \\
9 \\
3 \\
3 \\
1 \\
2 \\
2 \\
4 \\
+ \\
+ \\
+ \\
+\end{array}$ & $\begin{array}{l}215 \\
171 \\
193 \\
238 \\
86 \\
178 \\
118 \\
245 \\
221 \\
205 \\
210 \\
227 \\
16 \\
10 \\
\end{array}$ \\
\hline $\begin{array}{l}70 X-6,25-26 \\
70 X-7,25-26 \\
70 X-c C \\
71 X-1,25-26 \\
71 X-3,25-26 \\
71 X-4,25-26\end{array}$ & $\begin{array}{l}649.75 \\
651.25 \\
651.7 \\
651.95 \\
654.95 \\
656.45 \\
\end{array}$ & $\begin{array}{c}\text { Cavitatus } \\
\text { rectus }\end{array}$ & 1 & $\begin{array}{l}1 \\
+ \\
+ \\
+ \\
+\end{array}$ & $\begin{array}{l}+ \\
+ \\
1 \\
2 \\
\end{array}$ & & i & $\begin{array}{l}1 \\
3 \\
1 \\
2 \\
1 \\
5 \\
\end{array}$ & $\begin{array}{l}+ \\
+ \\
+ \\
+ \\
1 \\
+ \\
(2)\end{array}$ & + & & $\begin{array}{l}+ \\
5 \\
1 \\
2 \\
6 \\
\end{array}$ & $\begin{array}{l}+ \\
+ \\
+ \\
+ \\
+ \\
+\end{array}$ & & $\begin{array}{l}+ \\
+\end{array}$ & (+) & & i & & $\begin{array}{l}2 \\
2 \\
3 \\
3 \\
5 \\
8 \\
\end{array}$ & & $\begin{array}{l}34 \\
37 \\
29 \\
34 \\
31 \\
36 \\
\end{array}$ & $\begin{array}{r}12 \\
9 \\
5 \\
3 \\
9 \\
9 \\
\end{array}$ & $\begin{array}{l}4 \\
+ \\
4 \\
3 \\
7 \\
6 \\
6\end{array}$ & $\begin{array}{r}3 \\
20 \\
2 \\
8 \\
10 \\
10 \\
\end{array}$ & $\begin{array}{l}+ \\
1 \\
+ \\
+ \\
1 \\
2 \\
\end{array}$ & $\begin{array}{l}234 \\
237 \\
229 \\
234 \\
231 \\
236 \\
\end{array}$ \\
\hline $\begin{array}{l}71 X-5,25-26 \\
71 X-6,25-26 \\
71 X-7,25-26\end{array}$ & $\begin{array}{l}657.95 \\
659.45 \\
660.95\end{array}$ & R. vigilans & 2 & $\begin{array}{l}1 \\
3 \\
1 \\
\end{array}$ & 1 & & 1 & $\begin{array}{l}3 \\
8 \\
6 \\
\end{array}$ & $\begin{array}{l}(+) \\
(10) \\
(4)\end{array}$ & + & & $\begin{array}{l}4 \\
2 \\
2\end{array}$ & $\begin{array}{l}+ \\
+ \\
1\end{array}$ & & $\stackrel{+}{i}$ & & & 1 & & $\begin{array}{l}+ \\
4 \\
2 \\
\end{array}$ & & $\begin{array}{l}37 \\
22 \\
11\end{array}$ & $\begin{array}{l}11 \\
11 \\
4 \\
\end{array}$ & $\begin{array}{l}4 \\
4 \\
6 \\
\end{array}$ & $\begin{array}{l}1 \\
4 \\
5 \\
\end{array}$ & $\begin{array}{l}1 \\
4 \\
6 \\
\end{array}$ & $\begin{array}{l}237 \\
222 \\
139 \\
\end{array}$ \\
\hline $\begin{array}{l}\text { 71X-CC } \\
72 \mathrm{X}-\mathrm{CC} \\
73 \mathrm{XCC} \\
74 \mathrm{X}-\mathrm{CC}\end{array}$ & $\begin{array}{l}661.3 \\
671.0 \\
678.02 \\
690.2\end{array}$ & Unzoned & & & & & 1 & 4 & $\begin{array}{l}(3) \\
(2) \\
(2)\end{array}$ & & & $\begin{array}{l}1 \\
1\end{array}$ & 2 & & & & & & & + & & $\begin{array}{r}19 \\
1\end{array}$ & $\begin{array}{l}5 \\
2 \\
1\end{array}$ & $\begin{array}{l}2 \\
7 \\
i\end{array}$ & $\begin{array}{l}3 \\
1 \\
1\end{array}$ & $\begin{array}{l}4 \\
1 \\
2 \\
2\end{array}$ & $\begin{array}{r}161 \\
20 \\
109 \\
33\end{array}$ \\
\hline
\end{tabular}

warmer sea-surface temperatures. As revealed by Figure 2 and Table 1 , the FOs of a number of diatom taxa are rather distinct and spaced throughout the section, whereas LOs tend to be more sporadic and difficult to recognize. It is possible that some diatom taxa are reworked from outcrops higher on the flank of the Detroit Seamount, but without more knowledge of the true LOs of various taxa in the North Pacific, it is difficult to assess the extent of reworking. Indeed, an unconformity separating lower Oligocene sediments below from upper lower Miocene sediments above was recorded in the core catcher of Core 145-883B-68X, which lies on the top of Detroit Seamount (Shipboard Scientific Party, 1993a) (Fig.1).

\section{Zonation}

A late Oligocene and early early Miocene diatom zonation for the North Pacific is proposed in the following section based on the ranges 


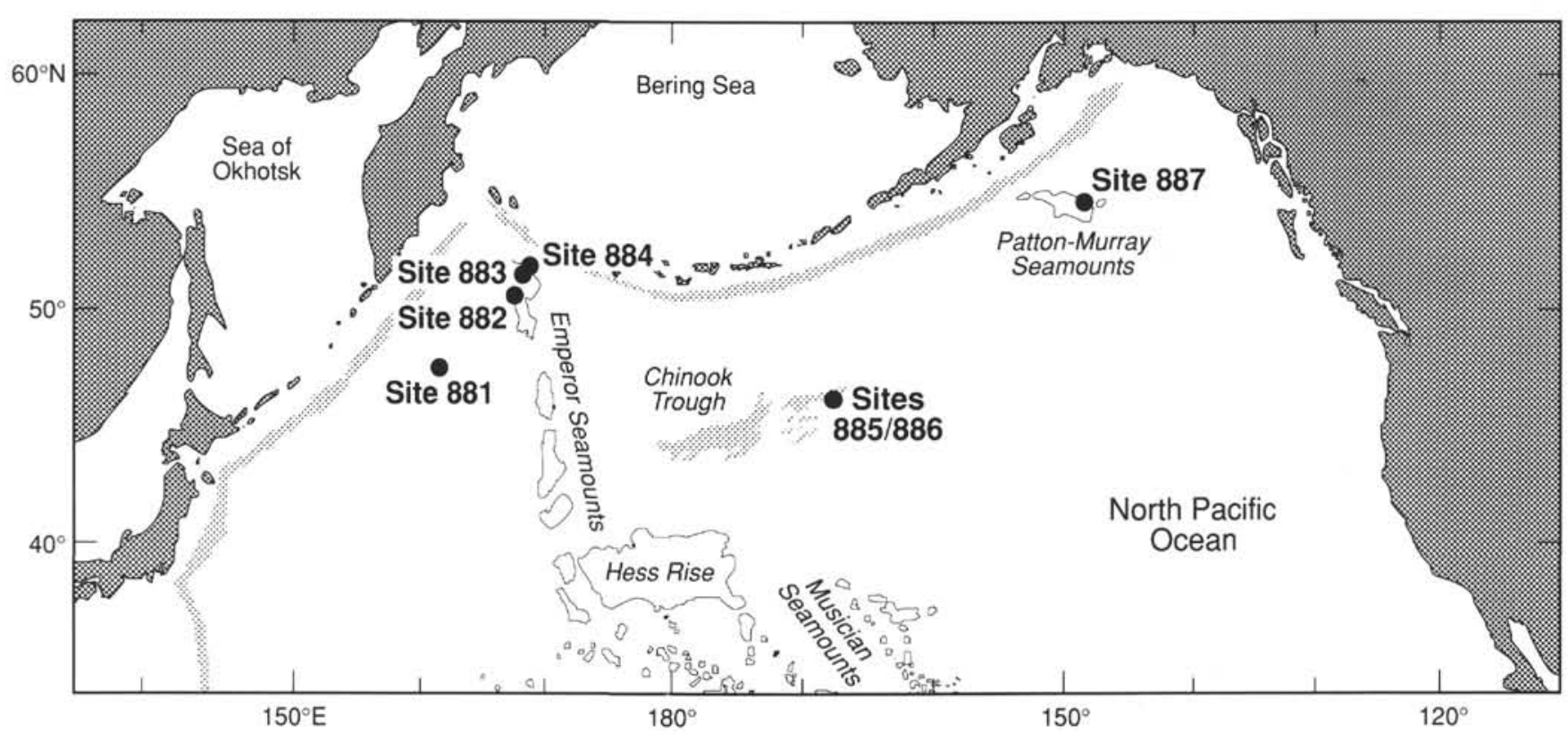

Figure 1. Location of Site 884 and other Leg 145 sites in the North Pacific.

of diatoms in Hole 884B (Fig. 2). The papers of Fenner (1985), Barron (1985a), Akiba et al.'s (1993), and Harwood and Maruyama (1992) have been consulted in an effort to give this zonation a widespread geographic application. The present zonation follows the example of Akiba's (1986) North Pacific diatom zonation for the late early Miocene through Pliocene in that it is based entirely on successive FOs of diatom taxa and it uses partial range zones.

An age vs. depth plot (sedimentation curve; Fig. 3) for the Oligocene and lower Miocene sediments of Hole 884B has been constructed using diatom, calcareous nannofossil, and radiolarian datum levels that have been tied to the paleomagnetic stratigraphy (Table 2) as well as to selected magnetostratigraphic events that are recognizable in Hole 884B. All of the pre-20 Ma calibrations of microfossil datum levels to magnetostratigraphy are from the tropical oceans or the Southern Ocean, so this age vs. depth plot should be considered tentative. Nevertheless, the datum levels line up on a relatively straight line, although the LOs of the calcareous nannofossil Reticulofenestra bisecta and the diatom Lisitzinia ornata fall some distance from this line, with the former occurring below (or older) and the latter occurring above (or younger) than expected (Fig. 3). The earlier LO of $R$. bisecta is probably caused by selective preservation, because carbonate is sparse in the upper Oligocene to lower Miocene sediments of Hole 884B (Shipboard Scientific Party, 1993b). Reworking of Oligocene diatoms upsection, on the other hand, may result in a younger LO for $L$. ornata (Table 1).

This age vs. depth plot suggests continuous sedimentation at Site 884 during the Oligocene and early Miocene, although it is possible that the interval between 31.7 and $30.2 \mathrm{Ma}$ is removed at an unconformity at about $660 \mathrm{mbsf}$ (alternative 2) (see Shipboard Scientific Party, 1993b). In the following section the proposed late Oligocene and early Miocene diatom zonation is discussed along with stratigraphically significant diatom occurrences.

\section{DIATOM ZONES}

\section{Rocella vigilans Partial Range Zone}

Definition: Interval from the FO of Rocella vigilans to the $\mathrm{FO}$ of Cavitatus rectus

Age: $~ 30.2$ Ma (Subchron C11r.2r, Southern Ocean, Harwood and Maruyama, 1992) to $\sim 29.6 \mathrm{Ma}$ (estimated ages at Site 884 , this report)

Authors: New zone, modified from the $R$. vigilans Zone of Fenner (1984) for use in the North Pacific. Fenner's (1984) R. vigilans Zone is defined as the range of $R$. vigilans below the FO of Bogorovia veniamini, which is a warm-water taxon that is extremely sparse in the North Pacific.

Remarks: Cestodiscus kugleri, C. trochus, Thalassiosira dubiosa, and $T$. mediaconvexa all have FOs in Hole 884B that closely approximate the base of the $R$. vigilans Zone; however, it is possible that these taxa may have older ranges than $R$. vigilans because an interval of relatively poor preservation lies immediately below the $R$. vigilans Zone in Hole 884B (Fig. 2). The robust, resistant nature of $R$. vigilans, along with the near coincidence of its FO in Hole 884B (estimated at $30.2 \mathrm{Ma}$ ) with the $\mathrm{LO}$ of the calcareous nannofossil Reticulofenestra umbilica (31.72 Ma) (Table 2), argue that the FO of $R$. vigilans in Sample 145-884B-70X-7, 25-26 cm, is not dissolution controlled. This is the first reported occurrences of Thalassiosira dubiosa in the North Pacific.

Rocella semigelida first occurs in the $R$. vigilans Zone, but it becomes common in the overlying Cavitatus rectus Zone (Fig. 2),

\section{Cavitatus rectus Partial Range Zone}

Definition: Interval from the FO of Cavitatus rectus to the FO of Rocella gelida

Age: $\sim 29.6-28.2 \mathrm{Ma}$ (estimated ages at Site 884 , this report)

Authors: New zone, modified from the $C$. rectus Zone of Akiba et al. (1993). Akiba et al. (1993) propose a C. rectus Interval Zone as the interval between the LO of Rocella gelida and the FO of Thalassiosira fraga. It is difficult, however, to determine the LO of $R$. gelida, because it is a resistant species that is easily reworked.

Secondary marker: The LO of Kozloviella minor is a secondary marker for the top of the $C$. rectus Zone.

Remarks: The FO of Cavitatus linearis falls just above the base of the zone in Hole 884B (Fig. 2). Thalassiosira dubiosa and Rocella semigelida are restricted to the lower part of the $C$. rectus Zone, whereas Kozloviella minor is restricted to the upper part of the zone. This is the first reported occurrence of $K$. minor in the North Pacific.

\section{Rocella gelida Partial Range Zone}

Definition: Interval from the FO of Rocella gelida to the FO of Thalassiosira praefraga

Age: $\sim 28.2$ to $\sim 24.0 \mathrm{Ma}$ (estimated ages at Site 884 , this report)

Authors: New zone, modified from the $R$. gelida Zone of Gombos and Ciesielski (1983), the R. gelida Zone of Barron (1983), and the R. gelida Zone of Baldauf and Barron (1991).

Secondary marker: The FO of Kisseleviella ezoensis closely approximates the top of the zone (Fig. 2).

Remarks: Gombos and Ciesielski (1983) proposed a $R$. gelida Concurrent-Range Zone for the Southern Ocean as the interval from the FO of $R$. 


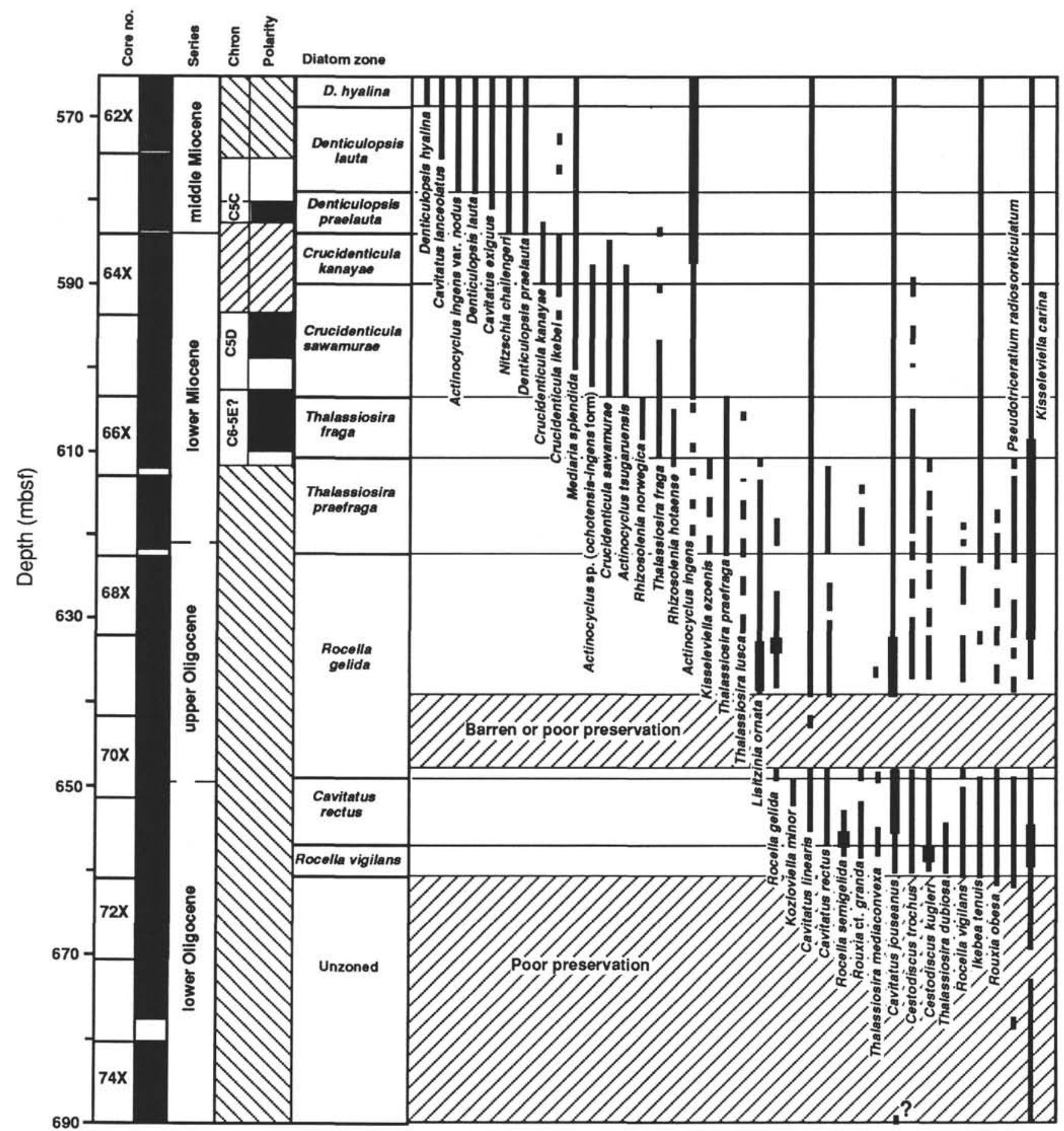

Figure 2. Ranges of stratigraphically important diatoms in the Oligocene to lower middle Miocene of Hole 884B referenced to diatom zones and depth in the core. Thicker parts of range bars indicate relatively common occurrences of the taxon; dashed range bar indicates discontinuous occurrences. Magnetostratigraphy is from Shipboard Scientific Party (1993b), with some modifications suggested by Barron and Gladenkov (this volume). Core recovery is indicated by black-filled intervals.

gelida to the LO of Rossiella sp. Barron (1983) recognized a $R$. gelida Partial Range Zone in the equatorial Pacific as the range of $R$. gelida below the FO of Rossiella paleacea. In the Southern Ocean, Baldauf and Barron (1991) modified the top of the $R$. gelida Zone of Gombos and Ciesielski (1983) to be the FO of Thalassiosira spumellaroides. Unfortunately, neither $R$. paleacea nor $T$. spumellaroides are present in the North Pacific, making them poor choices for marker species for a $R$. gelida Partial Range Zone. However, Barron (1983) and Baldauf and Barron (1991) report forms recorded as Thalassiosira spinosa $\mathrm{Schrader}$, which are equivalent to T. praefraga sp. nov. of this report (Barron, unpublished data), in lowermost Miocene sediments in the equatorial Pacific and Southern Ocean, so there is some possibility that a $R$. gelida Partial Range Zone, defined as the range of $R$. gelida below the FO of $T$. praefraga can be recognized in all three regions.

The FO of Rocella gelida in Sample 145-884B-70X-5, 25-26 cm is immediately below an interval of poor preservation ranging up through Sample 145-884B-69X-5, 25-26 cm (Table 1; Fig. 2). The FO of Lisitzinia ornata is immediately above this interval of poor preservation (Table 1).

The LO of Thalassiosira mediaconvexa and the FO of $T$. lusca fall within the R. gelida Zone in Hole 884B (Fig. 2). This is the first reported occurrence of $T$. lusca in the North Pacific. 


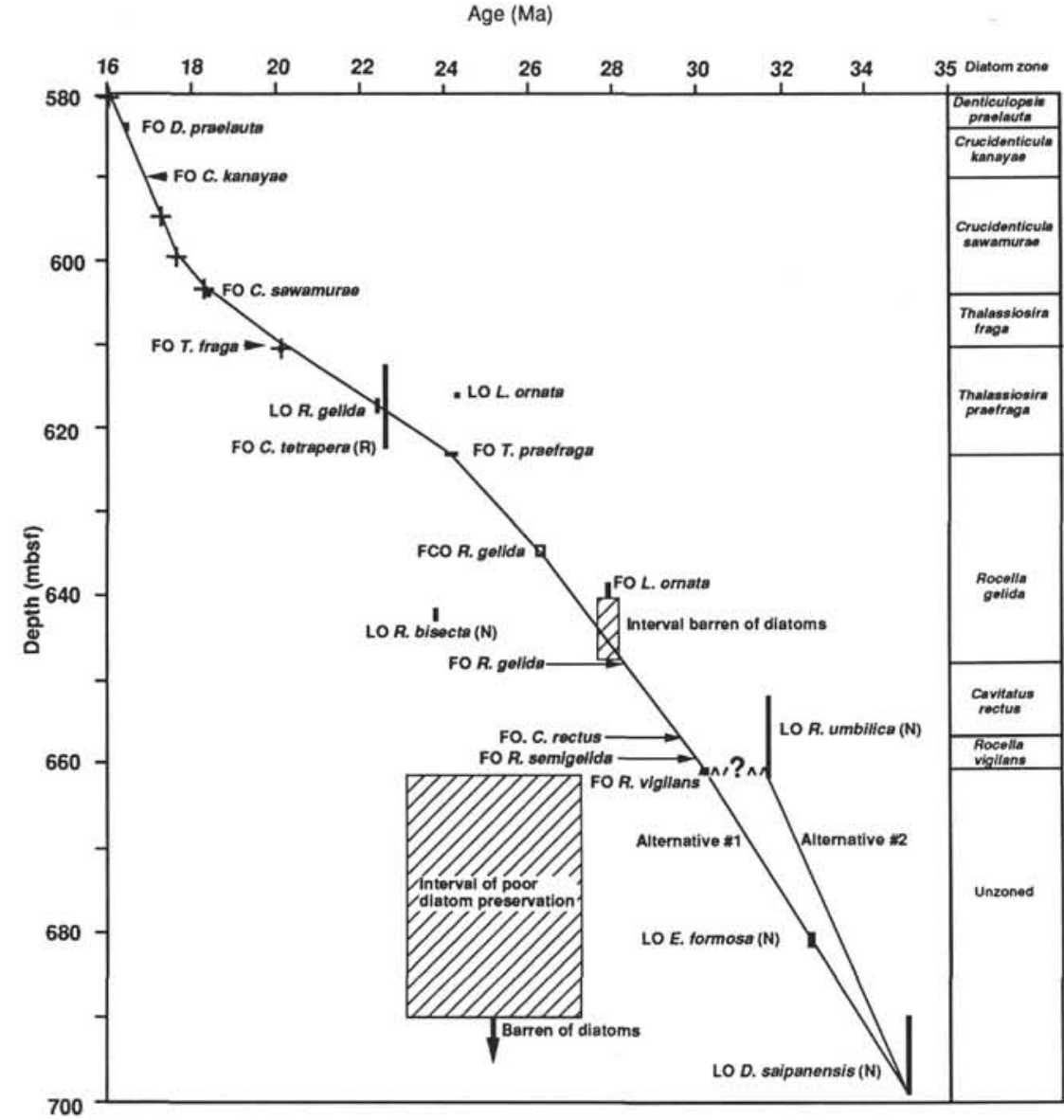

Figure 3. Age vs. depth plot of the Oligocene and lower Miocene portion of Hole 884B based on diatom, calcareous nannofossil $(\mathrm{N})$, and radiolarian $(\mathrm{R})$ events, and on paleomagnetic events $(+)$ (Table 2$)$. FCO $=$ first common occurrence; ${ }^{\wedge \wedge \wedge}=$ possible unconformity. Bar shows depth constraint of the microfossil events. Two alternatives are shown for the lower Oligocene.

\section{Thalassiosira praefraga Partial Range Zone}

Definition: Interval from the FO of Thalassiosira praefraga to the FO of T. fraga

Age: $~ 24.0-20.3 \mathrm{Ma}$ (Subchron C6r.1r?) (estimated ages at Site 884, this report)

Author: New name for T. spinosa Zone of Barron, 1985a

Remarks: In Hole 884B, the total range of Kisseleviella ezoensis closely approximates the entire T. praefraga Zone. Akiba (1986), however, indicates that $K$. ezoensis ranges up to the top of his Thalassiosira fraga Zone at DSDP Site 439 off Japan.

The LOs of Rocella vigilans, R. gelida, Rouxia sp. cf. R. granda, R. obesa, and Cestodiscus kugleri all fall within the T. praefraga Zone (Fig. 2); however, these taxa have fairly sporadic occurrences (Table 1), so caution should be used in applying these diatom events for long-range correlation. For example, Akiba et al. (1993) show more limited occurrences of Rocella vigilans, $R$. gelida, and Rouxia obesa in the Okubonosawa section of eastern Hokkaido.

The FO of Rhizosolenia hotaense and the LO of Cavitatus rectus fall just below the FO of Thalassiosira fraga, near the top of the T. praefraga Zone, in Hole 884B. A similar relationship between the LO of $C$. rectus and the FO of $T$. fraga is reported by Akiba et al. (1993) in the Okubonosawa section of eastern Hokkaido, further supporting the stratigraphic utility of these two diatom events.

The last consistent occurrence of Lisitzinia ornata in Sample 145-884B$67 \mathrm{X}-1,24-25 \mathrm{~cm}(613.54 \mathrm{mbsf})$ lies in the upper part of the $T$. praefraga Zone in Hole 884B (Table 1; Fig. 2). This relatively young LO is somewhat surprising, because $L$ ornata has a $\mathrm{LO}$ below the FO of Rocella gelida in the Okubonosawa section of eastern Hokkaido (Akiba et al., 1993), whereas the LO of $L$. ornata lies well below the LO of $R$. gelida in the Southern Ocean, according to Harwood and Maruyama (1992).

Also coinciding with the top of the T. praefraga Zone in Hole 884B is the last sporadic occurrence of Pseudotriceratium radiosoreticulatum. Akiba (1986) records the LO of $P$. radiosoreticulatum (as $P$. cheneiveri) at the top of his $T$. fraga Zone at Site 439 off Japan, a somewhat younger range than in Hole 884B.

\section{Thalassiosira fraga Partial Range Zone}

Definition: Interval from the FO of Thalassiosira fraga to the FO of Crucidenticula sawamurae

Age: $20.3 \mathrm{Ma}$ (Subchron C6r.1r?) to $18.4 \mathrm{Ma}$ (Subchron C5En.1n) (magnetostratigraphic correlation in Hole 884B)

Author: Modified from the T. fraga Zone of Barron (1985b). Barron (1985b) proposed a $T$. fraga Zone based on the range of $T$. fraga below the FO of Actinocyclus ingens. As mentioned below, isolated specimens of $A$. ingens range well down into the early Miocene, making its FO difficult to recognize. This zone was referred to Akiba and Yanagisawa (unpublished data) by Akiba et al. (1993) but it has not been published.

Remarks: Barron (1992) has argued for the near coincidence of the FOs of $C$. sawamurae (previously recorded as C. nicobarica or Denticulopsis nicobarica) and Actinocyclus ingens. In Hole 884B, forms referable to A. ingens, however, were observed well below the $\mathrm{FO}$ of $C$. sawamurae and down into the T. praefraga Zone (Table 1).

The total range of Rhizosolenia norwegica is restricted to the $T$. fraga Zone in Hole $884 \mathrm{~B}$, and $R$. hotaense has its LO within the zone.

The FO of Azpeitia praenodulifera in Hole 884B can be found in Sample 145-884B-66X-3, 25-26 cm (Table 1), above the FO of $T$. fraga (Sample $145-884 \mathrm{~B}-66 \mathrm{X}-5,25-26 \mathrm{~cm}$ ), a younger FO for this warm-water taxon than what was recorded by Barron (1983) in the equatorial Pacific.

A single common occurrence of Nitzschia maleinterpretaria is reported in Sample 145-884B-66X-2, 25-26 cm, just below the FO of Crucidenticula sawamurae in Sample 145-884B-65X-CC, which marks the top of the T. fraga Zone (Table 1). It is interesting to note that Yanagisawa and Akiba (1990) record an isolated abundance peak of $N$. maleinterpretaria immediately below the FO of C. sawamurae in equatorial Pacific Site 71, and it is tempting to think that the two occurrences may be time equivalent. This is the first recorded occurrence of $N$. maleinterpretaria in the North Pacific.

The restriction of the Thalassiosira fraga Zone to the interval from Samples $145-884 \mathrm{~B}-66 \mathrm{X}-1,25-26 \mathrm{~cm}$, to $-66 \mathrm{X}-5,25-26 \mathrm{~cm}(603.8-610.05$ mbsf or about $6.2 \mathrm{~m}$ total thickness) contrasts with its greater thickness $(25 \mathrm{~m})$ in Hole 883B (Barron and Gladenkov, this volume). Lithologic evidence for 
Table 2. Stratigraphic occurrence and age of diatom, calcareous nannofossil, radiolarian, and magetostratigraphic events in the Oligocene and lower middle Miocene section of Hole 884B.

\begin{tabular}{|c|c|c|c|c|c|c|}
\hline & Datum & $\begin{array}{l}\text { Age } \\
\text { (Ma) }\end{array}$ & Source & Region & Interval & $\begin{array}{l}\text { Depth } \\
\text { (mbsf) }\end{array}$ \\
\hline $\mathrm{T}$ & C5ACn.In & 14.059 & & & & 559.0 \\
\hline $\mathrm{FO}$ & Denticulopsis hyalina & $14.9-15.1$ & 1 & Site 887 & $62 X-4,25-26 \mathrm{~cm}$, to $62 X-6,25-26 \mathrm{~cm}$ & $567,05-570.05$ \\
\hline $\mathrm{T}$ & C5Cn.In? & 16.035 & & & & 580.0 \\
\hline FO & Denticulopsis lauta & 15.9 & 2 & North Pacific & $63 \mathrm{X}-3,25-26 \mathrm{~cm}$, to $63 \mathrm{X}-4,25-26 \mathrm{~cm}$ & $578.05-579.55$ \\
\hline FO & Denticulopsis praelauta & 16.2 & 2 & North Pacific & $63 \mathrm{X}-\mathrm{CC}$ to $64 \mathrm{X}-1,25-26 \mathrm{~cm}$ & $583.83-584.65$ \\
\hline $\mathrm{T}$ & C5Dn.In? & 17.31 & & & & 594.2 \\
\hline B & C5Dn.In? & 17.65 & & & & 599.0 \\
\hline $\mathrm{T}$ & C5En.In? & 18.317 & & & & 602.8 \\
\hline $\mathrm{FO}$ & Crucidenticula sawamurae & $18.3-18.5$ & 1 & Site 887 & $65 \mathrm{X}-\mathrm{CC}$ to $66 \mathrm{X}-1,25-26 \mathrm{~cm}$ & $603.8-604.05$ \\
\hline B & C6n. In? & 20.162 & & & & 610.0 \\
\hline FO & Thalassiosira fraga & 20.1 & 4 & Southern Ocean & $66 \mathrm{X}-5,25-26 \mathrm{~cm}$, to $66 \mathrm{X}-6,25-26 \mathrm{~cm}$ & $610.05-611.55$ \\
\hline LO & Lisitzinia ornata & 24.3 & 3 & Southern Ocean & $66 \mathrm{X}-\mathrm{C} C$ to $67 \mathrm{X}-1,25-26 \mathrm{~cm}$ & $613.3-613.55$ \\
\hline FO & Cyrtocapsella tetrapera & 22.6 & 5 & Mid latitudes & $66 \mathrm{X}-\mathrm{CC}$ to $67 \mathrm{X}-\mathrm{CC}$ & $613.3-632.4$ \\
\hline LO & Rocella gelida & 22.4 & 2 & Equatorial Pacific & $67 X-3,25-26 \mathrm{~cm}$, to $67 X-4,25-26 \mathrm{~cm}$ & $616.54-618.04$ \\
\hline FO & Thalassiosira praefraga & $24.0-24.3$ & 4 & Southern Ocean & $67 \mathrm{X}-\mathrm{CC}$ to $68 \mathrm{X}-1,25-26 \mathrm{~cm}$ & $622.8-623.05$ \\
\hline FCO & Rocella gelida & $26.2-26.4$ & 3 & Southern Ocean & $69 \times-2,25-26 \mathrm{~cm}$, to $69 \mathrm{X}-3,25-26 \mathrm{~cm}$ & $634.15-635.55$ \\
\hline FO & Lisitzinia ornata* & 27.9 & 3 & Southern Ocean & $69 \mathrm{X}-5,25-26 \mathrm{~cm}$, to $69 \mathrm{X}-6,25-26 \mathrm{~cm}$ & $638.65-640.15$ \\
\hline LO & Reticulofenestra bisecta & 23.8 & 5 & Mid latitudes & $69 \mathrm{X}-\mathrm{CC}$ to $70 \mathrm{X}-1,48 \mathrm{~cm}$ & $642.0-642.48$ \\
\hline FO & Rocella vigilans & 30.2 & 3 & Southern Ocean & $71 X-7,25-26 \mathrm{~cm}$, to $71 \mathrm{X}-\mathrm{CC}$ & $660.95-661.3$ \\
\hline LO & Reticulofenestra umbilica & 31.7 & 5 & Mid latitudes & $70 \mathrm{X}-\mathrm{CC}$ to $71 \mathrm{X}-\mathrm{CC}$ & $651.7-661.3$ \\
\hline LO & Erisonia formosa & 32.7 & 5 & Mid latitudes & $73 \mathrm{X}-\mathrm{CC}$ to $74 \mathrm{X}-1.50 \mathrm{~cm}$ & $680.6-681.1$ \\
\hline LO & Discoaster saipanenesis & 35.0 & 5 & Mid latitudes & $74 \mathrm{X}-\mathrm{CC}$ to $75 \mathrm{X}-\mathrm{CC}$ & $690.2-699.8$ \\
\hline
\end{tabular}

Notes: C. tetrapera is a radiolarian; R. bisecta, R. umbilica, E. formosa, and D. saipanensis are calcareous nannofossils. Ages are according to the Cande and Kent (1992) geomagnetic polarity time scale. Asterisk $(*)=$ above interval of dissolution. Sources for microfossil events are as follows: $I=B$ arron and Gladenkov (this volume), $2=B$ arron $(1992), 3=$ Harwood and Maruyama (1992), 4 = Baldauf and Barron (1991), and $5=$ Shipboard Scientific Party $(1993 \mathrm{a}) . \mathrm{T}=$ top of initial occurrence, $\mathrm{B}=$ bottom of initial occurrence, FO = first occurrence, $\mathrm{LO}=$ last occurrence, and $\mathrm{FCO}=$ first common occurrence.

compression of the $T$. fraga Zone in Hole $884 \mathrm{~B}$ includes the bioturbated nature of the sediments and the presence of sharp color contacts that may represent surfaces of erosion or nondeposition (see Core 145-884B-66X description in Shipboard Scientific Party, 1993b).

\section{Crucidenticula sawamurae Partial Range Zone}

Definition: Interval from the FO of Crucidenticula sawamurae to the FO of C. kanayae

Age: $18.4 \mathrm{Ma}$ (Subchron C5En.1n) to $16.9 \mathrm{Ma}$ (Subchron C5Cr.3r) (magnetostratigraphic correlation in Hole 884B)

Author: This zone is referred to Akiba and Yanagisawa (unpublished data) by Akiba et al. (1993), but it has not been published.

Remarks: The first consistent occurrence of Actinocyclus ingens coincides with the base of the C. sawamurae Zone (Table 1); however, sporadic occurrences of $A$. ingens can be found down into the $T$. praefraga Zone. Apparently, Barron (1980, 1985b) and Koizumi (1985) recognized this first consistent occurrence of $A$. ingens as the base of their $A$. ingens Zones.

The FO of Actinocyclus tsugaruensis and A. sp. (ochotensis-ingens form) also lie in the lowermost part of the C. sawamurae Zone in Hole 884B (Fig. 2).

The FO of Mediaria splendida can be found in the lower part of the $C$. sawamurae Zone, whereas the FO of Crucidenticula ikebe $i$ is near the top of the zone. At Site 439 off Japan, Akiba (1986) reports the FO of $M$. splendida in his Crucidenticula kanayae Zone, which is equivalent to the $C$. sawamurae and C. kanayae zones of this paper. Yanagisawa and Akiba (1990), however, suggest that the FOs of $C$. sawamurae and $C$. ikebe $i$ are equivalent.

The last consistent occurrence of Thalassiosira fraga lies in the C. sawamurae Zone in Hole 884B, but an isolated occurrence in Sample 145-884B$63 \mathrm{X}-\mathrm{CC}$ can be found in the lower part of the Denticulopsis praelauta Zone (Fig. 2; Table 1).

\section{Crucidenticula kanayae Partial Range Zone}

Definition: Interval from the FO of Crucidenticula kanayae to the FO of Denticulopsis praelauta

Age: 16.9 Ma (Subchron C5Cr.3r) to 16.3 Ma (Subchron C5Cn.1n) (magnetostratigraphic correlation in Hole 884B)

Author: This zone is referred to Akiba and Yanagisawa (in press) by Akiba et al. (1993), but it has not been published.

Remarks: The LO of Crucidenticula sawamurae lies near the top of the C. kanayae Zone, a younger range than what is suggested by Yanagisawa and Akiba (1990) off Japan. Also falling in the upper C. kanayae Zone are the LO of Azpeitia praenodulifera in Sample 145-884B-64X-1, 25-26 cm (Table 1), and the LOs of Actinocyclus tsugaruensis and A. sp. (ochotensis-ingens form)
(Fig. 2). At Site 439 off Japan, Akiba (1986) records a similar LO for Azpeitia praenodulifera in his C. kanayae Zone.

\section{Denticulopsis praelauta Partial Range Zone}

Definition: Interval from the FO of Denticulopsis praelauta to the FO of D. lauta

Age: $16.3 \mathrm{Ma}$ (Subchron C5Cn.1n) to $15.9 \mathrm{Ma}$ (Subchron C5Br.2r) (magnetostratigraphic correlation in Hole 884B)

Author: Akiba (1986)

Remarks: In Hole 884B, the FO of Nitzschia challengeri coincides with the FO of $D$. praelauta at the base of the D. praelauta Zone. In Holes 438B and 439 off Japan, however, the FO of $N$. challengeri is slightly above this horizon (Akiba, 1986; Yanagisawa and Akiba, 1990).

In the upper part of the D. praelauta Zone, Cavitatus exiguus first occurs, a stratigraphic occurrence supported by Akiba et al. (1993).

\section{Denticulopsis lauta Partial Range Zone}

Definition: Interval from the FO of Denticulopsis lauta to the FO of D. hyalina

Age: $15.9 \mathrm{Ma}$ (Subchron C5Br.2r) to $\sim 14.9 \mathrm{Ma}$ (Chron C5B) (magnetostratigraphic correlation from Holes 884B and 887A; Barron and Gladenkov, this volume)

Author: Maruyama (1984b)

Remarks: The FO of Cavitatus lanceolatus and the LO of Crucidenticula ikebei appear to fall in the D. lauta Zone in Hole 884B (Fig. 2). Akiba et al. (1993) report a similar FO for $C$. lanceolatus.

\section{TRANSPORTED DIATOMS}

Site 884 was positioned on the Meiji Drift, a sediment drift deposit occurring along the eastern flank of Emperor Seamount Chain that is more than $800 \mathrm{~km}$ long and $350 \mathrm{~km}$ wide (Scholl et al., 1977) (see Shipboard Scientific Party, 1993b). Lithologic Subunit IIA (604.8$694.7 \mathrm{mbsf}$ ), which encompasses the lower half of the section studied for diatom biostratigraphy, displays modest evidence for reworking in the form of sharp contacts, parallel laminae, and thin turbidites (Shipboard Scientific Party, 1993b). Within this interval, increased numbers of benthic diatoms, diatoms transported from shelf regions (Actinoptychus senarius and Paralia sulcata), and resting spores that are also normally associated with neritic environments are evidence of downslope transport (Table 1). However, backtracking of Site 884 
along the Hawaiian Seamount trend for the past 35 million years places it in the central North Pacific at about $40^{\circ} \mathrm{N}$ and $165^{\circ} \mathrm{W}$ (Shipboard Scientific Party, 1993b), far to the south of possible neritic source areas along the Aleutian Islands or in the Bering Sea. Together, these observations suggest extensive reworking of seafloor sediments in the North Pacific east of the Emperor Seamount Chain by bottom currents during the Oligocene and early Miocene.

\section{CONCLUSIONS}

The Oligocene through early middle Miocene diatom biostratigraphy of Hole 884B is documented, and 7 new partial range zones are proposed for the North Pacific based on the successive FO's of Rocella vigilans (30.2 Ma), Cavitatus rectus (29.6 Ma), Rocella gelida (28.3 Ma), Thalassiosira praefraga sp. nov. ( 24.0 Ma), Thalassiosira fraga (20.3 Ma), Crucidenticula sawamurae (18.4 Ma), and Crucidenticula kanayae (16.9 Ma). In the upper part of the interval studied in Hole $884 \mathrm{~B}$, the successive FOs of Denticulopsis praelauta, D. lauta, and $D$. hyalina are used to recognize the respective bases of the Denticulopsis praelauta, D. lauta, and D. hyalina Partial Range zones of Akiba (1986). Diatoms are generally common and are moderately-well to good preservation throughout the interval investigated, making Hole $884 \mathrm{~B}$ a unique reference section in the North Pacific for Oligocene and early Miocene.

Absolute age estimates for the interval from 20 to $14 \mathrm{Ma}$ are derived from magnetostratigraphy, whereas those in the interval from 30 to 20 $\mathrm{Ma}$ are suggested by an age vs. depth curve constructed from published age estimates of diatoms, calcareous nannofossils, and radiolarians from low-latitudes and the Southern Ocean. All ages are according to the geomagnetic polarity time scale of Cande and Kent (1992).

In addition to the ranges of the 10 marker species for the diatom zonation, the ranges of 27 other stratigraphically important diatom taxa are documented. Based of calcareous nannofossil biostratigraphy, Rocella vigilans has a FO in the early Oligocene which approximates its FO in the Southern Ocean ( 30.2 Ma). Rocella semigelida is documented for the first time in the North Pacific and found to range from the upper part of the $R$. vigilans Zone through the lower half of the overlying Cavitatus rectus Zone. Other taxa recorded for the first time in the North Pacific include Kozloviella minor, which is restricted to the upper part of the C. rectus Zone, and Nitzschia maleinterpretaria, which has a single common occurrence in the Thalassiosira fraga Zone. Rocella gelida appears to have originated in the North Pacific based on its apparent older FO ( 28.3 Ma) than what is reported by Harwood and Maruyama (1992) in the Southern Ocean (26.4-26.2 Ma). The FO of $R$. gelida in the Southern Ocean appears to coincide with the first common occurrence of $R$. gelida at Site 884 .

A new species, Thalassiosira praefraga is proposed for specimens previously identified as T. spinosa Schrader by Barron (1983, 1985a), Baldauf and Barron (1991), and us (in Rea, Basov, et al., 1993). Thalassiosira praefraga is sparse but consistent throughout the T. praefraga Zone, whereas Kisseleviella ezoensis is restricted (in very rare, sporadic occurrences) to the $T$. praefraga Zone.

Rocella vigilans, $R$. gelida, and Lisitzinia ornata lack sharp last occurrences in the lower Miocene (T. praefraga Zone) of Site 884. This may reflect reworking of Oligocene sediments at the site, which is consistent with sedimentologic and seismic evidence that these lower Miocene sediments have been redeposited by bottom currents.

The documentation of sparse specimens of Actinocyclus ingens through the Thalassiosira fraga and T. praefraga zones argues against previous practice of using the FO of $A$. ingens as a late early Miocene marker species. Nevertheless, $A$. ingens does become more consistent and more common in the late early Miocene at the base of the Crucidenticula sawamurae Zone (18.4 Ma).

The relatively common occurrence of benthic diatoms, Paralia sucata, Actinoptychus senarius, and Chaetoceros resting spores, especially in the Oligocene and lower Miocene sediments of Hole $884 \mathrm{~B}$, is evidence of transport of bottom sediments over at least 1200 $\mathrm{km}$ based on a probable source of these coastal and shallow water taxa near the Aleutian Islands and/or Bering Sea and on backtracking of Site 884 at $35 \mathrm{Ma}$ to a position of about $40^{\circ} \mathrm{N}$ and $165^{\circ} \mathrm{W}$ in the central North Pacific. These observations support sedimentologic and seismic evidence that Site 884 is located on an extensive sediment drift, the Meiji Drift, (Shipboard Scientific Party, 1993b).

\section{ACKNOWLEDGMENTS}

We thank Fumio Akiba, David Harwood, Elisabeth Fourtanier, Rainer Gersonde, Scott Starratt, and David Bukry for their helpful reviews and suggestions for improving the manuscript. Iwona Rek of the California Academy of Sciences aided with some Russian translations. The research of Andrey Gladenkov was supported by Grant \#93-05-9558 of the Russian Foundation for Fundamental Research and in part by a JOI travel grant to Russian scientists. Kevin Purcell of the U.S. Geological Survey aided in the assembly of the manuscript. We are grateful to David Rea, Ivan Basov, and the scientists and crew members of Leg 145 of the JOIDES Resolution for their support and encouragement. Samples were provided by the Ocean Drilling Program.

\section{REFERENCES}

Akiba, F., 1980. A lower Miocene diatom flora from the Boso Peninsula, Japan, and the resting spore formation of an extinct diatom, Kisseleviella carina Sheshukova-Poretzkaya. Bull. Tech. Lab., JAPEX, 23:81-100.

, 1986. Middle Miocene to Quaternary diatom biostratigraphy in the Nankai trough and Japan trench, and modified lower Miocene through Quaternary diatom zones for middle-to-high latitudes of the North Pacific. In Kagami, H., Karig, D.E., Coulbourn, W.T., et al., Init. Repts. DSDP, 87: Washington (U.S. Govt. Printing Office), 393-481.

Akiba, F., Hiramatsu, C., and Yanagisawa,Y., 1993. A Cenozoic diatom genus Cavitatus Williams; an emended description and two new biostratigraphically useful species, C. lanceolatus and C. rectus from Japan. Bull. Nat. Sci. Mus. Ser. C.: Geol. Paleontol. (Tokyo), 19:11-39.

Akiba, F., and Yanagisawa, Y., 1986. Taxonomy, morphology and phylogeny of the Neogene diatom zonal marker species in the middle-to-high latitudes of the North Pacific. In Kagami, H., Karig, D.E., Coulbourn, W.T., et al., Init. Repts. DSDP, 87: Washington (U.S. Govt. Printing Office), 483-554.

Baldauf, J.G., and Barron, J.A., 1980. Actinocyclus ingens var. nodus: a new stratigraphically useful diatom of the circum-North Pacific. Micropaleontology, 26:103-110.

1987. Oligocene marine diatoms recovered in dredge samples from the Navarin Basin province, Bering Sea. U.S. Geol. Surv. Bull., 1765.

, 1991. Diatom biostratigraphy: Kerguelen Plateau and Prydz Bay regions of the Southern Ocean. In Barron, J., Larsen, B., et al., Proc. ODP, Sci. Results, 119: College Station, TX (Ocean Drilling Program), 547-598.

Barron, J.A., 1980. Lower Miocene to Quaternary diatom biostratigraphy of Leg 57, off Northeastern Japan, Deep Sea Drilling Project. In von Huene, R., Nasu, N., et al., Init. Repts. DSDP, 56, 57 (Pt. 2): Washington (U.S Govt. Printing Office), 641-686.

1983. Latest Oligocene through early middle Miocene diatom biostratigraphy of the eastern tropical Pacific. Mar. Micropaleontol., 7:487-515.

, 1985a. Miocene to Holocene planktic diatoms. In Bolli, H.M. Saunders, J.B., and Perch-Nielsen, K. (Eds.), Plankton Stratigraphy: Cambridge (Cambridge Univ. Press), 763-809.

1985b. Late Eocene to Holocene diatom biostratigraphy of the equatorial Pacific Ocean, Deep Sea Drilling Project Leg 85. In Mayer, L. Theyer, F., Thomas, E., et al., Init. Repts. DSDP, 85: Washington (U.S. Govt. Printing Office), 413-456.

1992. Neogene diatom datum levels in the equatorial and North Pacific. In Ishizaki, K., and Saito, T. (Eds.), The Centenary of Japanese Micropaleontology: Tokyo (Tokyo Univ. Press), 413-425.

Berggren, W.A., Kent, D.V., and Flynn, J.J., 1985a. Jurassic to Paleogene: Part 2. Paleogene geochronology and chronostratigraphy. In Snelling, N.J.

\footnotetext{
- Abbreviations for names of organizations and publications in ODP reference lists follow the style given in Chemical Abstracts Service Source Index (published by American Chemical Society).
} 
(Ed.), The Chronology of the Geological Record. Geol. Soc. London Mem., 10:141-195.

Berggren, W.A., Kent, D.V., Flynn, J.J., and van Couvering, J., 1985b. Neogene geochronology and chronostratigraphy. In Snelling, N.J. (Ed.), The Chronology of the Geological Record. Geol. Soc. London Mem., 10:211250.

Cande, S.C., and Kent, D.V., 1992. A new geomagnetic polarity time scale for the Late Cretaceous and Cenozoic. J. Geophys. Res., 97:13917-13951.

Castracane, C.A.F., 1886. Report of the Scientific Results of the Voyage of H.M.S. Challenger during the Years 1873-1876. Botany, 2: London (H.M.S.O.).

Dolmatova, L.M., Lupikina, E.G., and Oreshkina, T.V., 1984. Diatom flora. In Menner, V.V. (Ed.), Atlas of Flora and Fauna of Neogene Sediments of the Far East: Moscow (Nauka), 67-70. (in Russian)

Fenner, J., 1984. Middle Eocene to Oligocene planktonic diatom stratigraphy from Deep Sea Drilling sites in the South Atlantic, equatorial Pacific, and Indian Oceans. In Hay, W.W., Sibuet, J.-C., et al., Init. Repts. DSDP, 75 (Pt. 2): Washington (U.S. Govt. Printing Office), 1245-1271.

1985. Late Cretaceous to Oligocene planktic diatoms. In Bolli, H.M., Saunders, J.B., and Perch-Nielsen, K. (Eds.), Plankton Stratigraphy: Cambridge (Cambridge Univ. Press), 713-762.

, 1991. Late Pliocene-Quaternary quantitative diatom stratigraphy in the Atlantic sector of the Southern Ocean. In Ciesielski, P.F., Kristoffersen, Y., et al., Proc. ODP, Sci. Results, 114: College Station, TX (Ocean Drilling Program), 97-121.

Fryxell, G.A., Sims, P.A., and Watkins, T.P., 1986. Azpeitia (Bacillariophyceae): related genera and promorphology. Syst. Bot. Monogr., 13:1-74.

Gladenkov, A.Y., 1988. The Paleogene diatom flora of the Komandorsky Islands (The Bering Sea). In Simola, H. (Ed.), Proc. 10th Int. Diatom Symp., Joensuu, Finland: Koenigstein (Koeltz Sci. Books), 243-247.

Gleser, Z.I., Dolmatova, L.M., and Lupikina, E.G., 1986. Marine Paleogene diatom algae of eastern Kamchatka. Bot. Zh. (Leningrad), 71:851-859. (in Russian)

Gombos, A.M., Jr., 1983. Survey of diatoms in the upper Oligocene and lower Miocene in Holes 515B and 516F, In Barker, P.F., Carlson, R.L., Johnson, D.A., et al., Init. Repts. DSDP, 72: Washington (U.S. Govt. Printing Office), 793-804.

Hajós, M., 1976. Upper Eocene and lower Oligocene Diatomaceae, Archaeomonadaceae, and Silicoflagellatae in southwestern Pacific sediments, DSDP Leg 29. In Hollister, C.D., Craddock, C., et al., Init. Repts. DSDP, 35: Washington (U.S. Govt. Printing Office), 817-883.

Harwood, D.M., 1986. Diatoms. In Barrett, P.J. (Ed.), Antarctic Cenozoic History from the MSSTS-1 Drillhole, McMurdo Sound. DSIR Bull. N.Z., 237:69-107.

Harwood, D.M., and Maruyama, T., 1992. Middle Eocene to Pleistocene diatom biostratigraphy of Southern Ocean sediments from the Kerguelen Plateau, Leg 120. In Wise, S.W., Jr., Schlich, R., et al., Proc. ODP, Sci. Results, 120: College Station, TX (Ocean Drilling Program), 683-733.

Heiden, H., and Kolbe, R.W., 1928. Die marinen Diatomeen der Deutschen Südpolar-Expedition 1901-1903. In von Drygalski, E. (Ed.), Deutsche Südpolar-Expedition, 1901-1903 (Vol. 8): Botanik: Berlin (Walter de Gruyter), 447-715.

Jousé, A.P., 1973. Diatoms in the Oligocene-Miocene biostratigraphic zones of the tropical areas of the Pacific Ocean. Nova Hedwigia Beih., 45:333357.

Kanaya, T., 1959. Miocene diatom assemblages from the Onnagawa Formation and their distribution in correlative formations in northeast Japan. Sci. Rep. Tohoku Univ., Ser. 2, 30:1-130.

Kim, W.H., and Barron, J.A., 1986. Diatom biostratigraphy of the upper Oligocene to lowermost Miocene San Gregorio Formation, Baja California Sur, Mexico. Diatom Res., 1:169-187.

Koizumi, I., 1968. Tertiary diatoms from the Oga Peninsula, Akita Prefecture, northeast Japan. Sci. Rep. Tohoku Univ., Ser. 2, 40:171-240.

, 1985. Diatom biochronology for the Late Cenozoic northwest Pacific. J. Geol. Soc. Japan, 91:195-211.

Lohman, K.E., 1974. Lower Miocene marine diatoms from Trinidad. Verhandl. Naturforsch. Ges. Basel, 84:326-360.

Maruyama, T., 1984a. Miocene diatom biostratigraphy of onshore sequences on the Pacific side of Northeast Japan, with reference to DSDP Hole 438A (Part 1). Sci. Rep. Tohoku Univ., Ser. 2, 54:141-164.

, 1984b. Miocene diatom biostratigraphy of onshore sequences on the Pacific side of Northeast Japan, with reference to DSDP Hole 438A (Part 2). Sci. Rep. Tohoku Univ., Ser. 2, 55:77-140.
Oreshkina, T.V., 1982. Marine diatoms from the Paleogene sediments of Karaginsky Island, eastern Kamchatka. In Jousé, A.P., and Krasheninnikov, V.A. (Eds.), Marine Micropaleontology: Moscow (Nauka), 159162. (in Russian)

Pushkar, V.A., 1987. Diatoms of Paleogene sediments of the northwest Pacific. In Markevich, V.A. (Ed.), Palynology of the Eastern USSR. Trans. USSR Acad. Sci., 60-70. (in Russian)

Rea, D.K., Basov, I.A., Janecek, T.R., Palmer-Julson, A., et al., 1993. Proc ODP, Init. Repts., 145: College Station, TX (Ocean Drilling Program).

Saito, T., Barron, J.A., and Sakamoto, M., 1988. An early late Oligocene age indicated by diatoms for a primitive Desmostylian mammal Behemotops from eastern Hokkaido, Japan. Proc. Jpn. Acad., Ser. B, 64:269-273.

Scholl, D.V., Hein, J.R., Marlow, M., and Buffington, E.C., 1977. Meiji sediment tongue: North Pacific evidence for limited movement between the Pacific and North American plates. Geol. Soc. Am. Bull., 88:15671576.

Schrader, H.-J., 1973. Cenozoic diatoms from the Northeast Pacific, Leg 18. In Kulm, L.D., von Huene, R., et al., Init. Repts. DSDP, 18: Washington (U.S. Govt. Printing Office), 673-797.

1976. Cenozoic planktonic diatom biostratigraphy of the Southern Pacific Ocean. In Hollister, C.D., Craddock, C., et al., Init. Repts. DSDP, 35: Washington (U.S. Govt. Printing Office), 605-671.

Schrader, H.-J., and Fenner, J., 1976. Norwegian Sea Cenozoic diatom biostratigraphy and taxonomy. In Talwani, M., Udintsev, G., et al., Init. Repts. DSDP, 38: Washington (U.S. Govt. Printing Office), 921-1099.

Shipboard Scientific Party, 1993a. Site 883. In Rea, D.K., Basov, I.A., Janecek, T.R., Palmer-Julson, A., et al., Proc. ODP, Init. Repts., 145: College Station, TX (Ocean Drilling Program), 121-208.

1993b. Site 884. In Rea, D.K., Basov, I.A., Janecek, T.R., PalmerJulson, A., et al., Proc. ODP, Init. Repts., 145: College Station, TX (Ocean Drilling Program), 209-302.

Simonsen, R., 1974. The diatom plankton of the Indian Ocean expedition of R/V Meteor, 1964-1965. In "Meteor" Forschunsergebnisse, Reihe D(No. 19): Biologie: Berlin-Stuttgart (Gebrüder Borntraeger).

Sims, P.A., Fryxell, G.A., and Baldauf, J.G., 1989. Critical examination of the diatom genus Azpeitia. Species useful as stratigraphic markers for the Oligocene and Miocene Epochs. Micropaleontology, 35:293-307.

Sundström, B.G., 1986. The marine diatom genus Rhizosolenia: a new approach to the taxonomy [Ph.D. dissert.]. Lund Univ., Sweden.

Tuzov, V.P., Boldyreva, V.P., and Gladenkov, A.Y., 1991. About the age of Pilengskaya and Daekhuriinskaya formations of Sakhalin. Tr. Akad. Nauk SSSR, Ser. Geol., 4:127-131. (in Russian)

Williams, D.M., 1988. An illustrated catalogue of the type specimens in the Greville diatom herbarium. Bull. Br. Mus. (Nat. Hist.) Bot., 18:1-148.

Yanagisawa, Y., and Akiba, F., 1990. Taxonomy and phylogeny of three marine diatom genera, Crucidenticula, Denticulopsis, and Neodenticula. Bull. Geol. Surv. Jpn., 41:197-301.

Yanagisawa, Y., and Suzuki, Y., 1987. Diatoms and silicoflagellates from the Oligocene Shirasaka Formation of the Joban Coalfield, northeast Japan. Bull. Geol. Surv. Jpn., 38:81-98. (in Japanese)

\section{Date of initial receipt: 5 April 1994 \\ Date of acceptance: 5 August 1994 \\ Ms 145SR-105}

\section{APPENDIX}

\section{TAXONOMY}

Thalassiosira praefraga A. Gladenkov et Barron, sp. nov. (Pl. 2, Figs. 3-6, 9)

Synonym. Thalassiosira spinosa Schrader sensu Barron, 1983, p. 512, pl. IV, fig. 8; sensu Barron, 1985a, p. 793, pl. 11, fig. 15; sensu Baldauf and Barron, 1991, p. 591; ?sensu Harwood and Maruyama, 1992, p. 708

Not Thalassiosira spinosa Schrader 1976, p. 636, pl. 6, figs. 5-7, or Thalassiosira spinosa var. aspinosa Schrader 1976, p. 636, pl. 6, fig. 3

Description. Valves convex, circular $12-24 \mu \mathrm{m}$ in diameter. Hexagonalrounded areolae cover the entire valve surface. Areolae in convex lines and curved tangential rows, sometimes appearing fasciculated. Areolae 10-12 in $10 \mu \mathrm{m}$ in the valve's center, decreasing in size toward the margin (to $14-15$ in $10 \mu \mathrm{m})$. Margin 1-1.5 $\mu \mathrm{m}$ wide with radial striae and small, indistinct, 
irregularly situated strutted spines (processes), approximately $1.5-2 \mu \mathrm{m}$ apart with a length of $0.5-1 \mu \mathrm{m}$.

Remarks. Previously (Rea, Basov, et al., 1993), these specimens were tabulated as Thalassiosira spinosa Schrader and were used as the basis of the Thalassiosira spinosa Zone. However, Fumio Akiba (written comm., 1994) correctly pointed out that Thalassiosira spinosa Schrader 1976 is a junior homonym of Thalassiosira spinosa Simonsen, 1974, pp. 10-11, pls. 4-5.

Compared with Schrader's (1976, p. 636) description of T. spinosa and $T$. spinosa var. aspinosa, the specimens illustrated and described here have less strongly convex valves, finer areolation, and their areolae display a greater decrease in the size from the center of the valve to the valve's margin. Consequently, it seems inappropriate to rename Schrader's taxa.

Thalassiosira praefraga sp. nov. differs from Thalassiosira fraga Schrader emend Akiba and Yanagisawa, 1986 (p. 498, pl. 51, figs. 5-10, pl. 53 , figs. 1-8) by the nonlinear pattern of its areolae and its lack of a prominent strutted processes (4-5 in $10 \mu \mathrm{m}$ with a 1.5- $\mu \mathrm{m}$-long tube) around its margin.

Holotype. Pl. 2, Fig. 9, Sample 145-884B-66X-5, 25-26 cm (specimen deposited in the Institute of the Lithosphere, Russian Academy of Sciences, Moscow)

Isotypes. Pl. 2, Fig. 4, Sample 145-884B-66X-4, 25-26 cm; Pl. 2, Fig. 6, Sample 145-884B-67X-CC (specimens deposited in the Institute of the Lithosphere, Russian Academy of Sciences, Moscow)

Derivation of name: A combination of "prae" (Latin, = before) plus "fraga" (from Thalassiosira fraga Schrader). Thalassiosira praefraga sp. nov. occurs stratigraphically below $T$. fraga and may be its ancestor.

\section{Taxonomic Notes and References to Good Figures}

Taxonomic references to diatom taxa tabulated in Hole 884B and illustrated on Plates 1-9 are listed below. In general, only references to good figures are listed following a semicolon. The reader should refer to these references for the original reference of the taxon. Important synonyms and limited remarks are included.

Actinocyclus ingens Rattray; Akiba, 1986, pl. 16, figs. 6, 9 (Pl. 7, Figs. 1, 2) Actinocyclus ingens var. nodus Baldauf in Baldauf and Barron, 1980, pl. 1, figs. 5-9 (Pl. 7, Fig. 7)

Actinocyclus octonarius Ehrenberg; Akiba, 1986, pl. 29, fig. 4=A. ehrenbergii Ralfs in Pritchard (PI. 6, Fig. 15)

Actinocyclus tsugaruensis Kanaya, 1959, p. 99, pl. 8, figs. 5-8 (Pl. 7, Figs. 3, 6)

Remarks. Unlike many previous authors, we have chosen not to include this form with $A$. ingens, because we feel it has a distinct morphology.

Actinocyclus sp. (ochotensis-ingens form) (Pl. 7, Figs. 4, 5)

Remarks. Forms resembling A. ochotensis Jousé, but probably related to A. ingens Rattray, are tabulated here.

Actinoptychus senarius (Ehrenberg) Ehrenberg; Akiba, 1986, p. 447, pl. 29, fig. 2 = A. undulatus (Bailey) Ralfs.

Asteromphalus sp. cf. A. darwinii Ehrenberg; Koizumi, 1968, pl. 32, fig. 7 (Pl. 9, Fig. 2)

Asteromphalus sp. aff. A. oligocenicus Schraderet Fenner, 1976, p. 965, pl. 21, figs. 8, 1, 14; pl. 28, fig. 1 (Pl. 9, Figs. 1, 6)

Asteromphalus sp. aff. A. robustus -symmetricus (PI. 9, Figs. 3, 7)

Remarks. Forms intermediate between A. robustus Castracane sensu Schrader (1973, pl, 21, figs. 4, 5, 7) and A. symmetricus Schrader and Fenner (1976, p. 966, pl. 21, figs. 7, 10-12)

Azpeitia biradiata (Greville) Sims in Fryxell et al. 1986, p. 7, figs. 4, 5, 27 $(1-3)=$ Coscinodiscus biradiatus Greville; Williams, 1988, p. 25, pl. 31, fig. 1 (Pl. 6, Fig. 23a-b)

Azpeitia oligocenica (Jousé) Sims in Sims et al., 1989, p. 302, pl. 2, figs. 1-3; pl. 3, figs. 8, 9 = Coscinodiscus oligocenicus Jousé; Barron, 1983, p. 512, pl. 3, figs. 8, 11 (PI. 5, Figs. 24, 26)

Azpeitia praenodulifera (Barron) Sims and Fryxell in Sims et al., 1989, p. 298 , pl. 1, figs. 8-13; pl. 3, fig. $11=$ Coscinodiscus praenodulifer Barron, 1983, p. 511, pl. 3, figs. 9, 10; pl. VI, fig. 8 (Pl. 2, Fig. 21)

Azpeitia sp. aff. A. praenodulifera (Barron) Sims et Fryxell (Pl. 3, Fig. 1) Remarks. Differs from A. praenodulifera by smaller size and coarser nature of areolae, less prominent marginal processes, and wider central hyaline area. Synonym. Coscinodiscus cf. nodulifer of Akiba, 1980, pl. 4, fig. 49

Azpeitia salisburyana (Lohman) Sims in Sims et al., 1989, p. 302, pl. 2, figs. 4-6; pl. 3, fig. 5 = Coscinodiscus salisburyanus Lohman (PI. 2, Fig. 20)

Azpeitia tabularis (Grunow) Fryxell et Sims in Fryxell et al., 1986, p. 16, figs. 14, 15, 30(1) (Pl. 3, Figs. 9, 11)

Remarks. A. endoi (Kanaya) Sims and Fryxell is regarded as a variant of A. tabularis and is tabulated here as such.
Cavitatus exiguus Yanagisawa et Akiba in Akiba et al., 1993, p. 18, figs. 5 , 1-11 (Pl. 5, Fig. 4)

Cavitatus jouseanus (Sheshukova-Poretzkaya) Williams; Akiba et al., 1993, p. 20, figs. 6, 19-20 = Synedra jouseana Sheshukova-Poretzkaya, 1967; Akiba, 1986, pl. 21, fig. 9 (Pl. 5, Figs. 3, 15, 18-19, 22-23)

Cavitatus lanceolatus Akiba et Hiramatsu in Akiba et al., 1993, p. 22, figs. 6 (1a-6b), 7 (1-7) (Pl. 5, Figs. 5, 6)

Cavitatus linearis (Sheshukova-Poretzkaya) Akiba et Yanagisawa in Akiba et al., 1993, p. 26, figs. $6(17-18), 8(1-10)=$ Synedra jouseana $\mathrm{f}$. linearis Sheshukova-Poretzkaya, 1967; Akiba, 1986, pl. 21, fig. 8 (Pl. 5, Figs. $16-17,25)$

Cavitatus miocenicus (Schrader) Akiba et Yanagisawa in Akiba et al. 1993, p. 29, fig. $9(1-11)=$ Synedra miocenica Schrader; Akiba, 1986, pl. 21, fig. 7 (Pl. 5, Figs. 1-2, 27)

Cavitatus rectus Akiba et Hiramatsu in Akiba et al., 1993, p. 28, fig. 6 (7-15) (Pl. 5, Figs, 7-10)

Cestodiscus kugleri Lohman, 1974, p. 340, pl. 4, figs. 4, 5, 8 = Cestodiscus aff. trochus Castracane sensu Fenner, 1984, p. 1270, pl. 1, fig. 4 (PI. 3, Figs. 2-6, 7?)

Remarks. A range of forms have been tabulated together under this taxon, because they seemed to intergrade with one another. Fumio Akiba (written comm., 1994) thinks that specimens with a hyaline center and nonfasciculated areolar pattern (i.e., pl. 3, fig. 7) represent a distinct species. A detailed taxonomic study of Cestodiscus spp. is needed.

Cestodiscus trochus Castracane, 1886, p. 123, pl. 7, figs. 1, 3 (Pl. 3, Figs. 8, 10) Chaetoceros spores (Pl. 2, Fig. 17; Pl. 9, Fig. 8)

Coscinodiscus lewisianus Greville; Schrader, 1973, pl. 8, figs. 1-6, 10, 15 (Pl. 3, Fig. 13)

Coscinodiscus lewisianus var. levis (Jousé) Harwood et Maruyama, 1992, p. 702, pl. 3, figs. 12-15 = Actinocyclus levis Jousé, 1973, p. 353, pl. 5, fig. 2 (Pl. 1, Figs. 14a-b)

Coscinodiscus marginatus Ehrenberg; Akiba, 1986, pl. 1, figs. 1-4 (Pl. 9, Figs. $4,5)$

Coscinodiscus rhombicus Castracane; Fenner, 1985, p. 729, pl. 7, figs. 1-4 (Pl. 3, Fig. 12)

Crucidenticula ikebei Akiba et Yanagisawa, 1986, p. 485, pl. 1, figs. 1-2 (Pl. 8 , Figs. 34,35 )

Crucidenticula kanayae Akiba et Yanagisawa, 1986, p. 486, pl. 1, figs. 3-8; pl. 3, figs. 1-6, 9-11 (Pl. 8, Figs. 37-40, 44-47)

Crucidenticula sawamurae Yanagisawa et Akiba, 1990, p. 227, pl. 1, figs. 5-9 $=$ Denticulopsis nicobarica (Grunow) Simosen; Barron, 1983, pl. 5, figs. 1, 2 (Pl. 8, Figs. 31-33, 36, 41-42)

Cymatosira sp. aff. C. lorenziana Grunow (PI. 5, Figs. 14, 20-21)

Remarks. This form has a hyaline central area like the form of Akiba, 1980, pl. 4, fig. 47.

Denticulopsis hyalina (Schrader) Simonsen; Akiba, 1986, pl. 26, figs. 20-25 (PI. 8, Fig. 43)

Denticulopsis lauta (Bailey) Simonsen; Akiba, 1986, pl. 26, Figs. 15-19 (Pl. 8, Figs. 20-26)

Denticulopsis praelauta Akiba et Koizumi; Akiba, 1986, pl. 26, figs. 10-14 (Pl. 8, Figs. 9-19)

Goniothecium decoratum Brun; Schrader and Fenner, 1976, pl. 6, figs. 3, 5; pl. 37 , figs. $1-4,33,5,11-14$ (Pl. 6, Fig. 22)

Goniothecium odontella Ehrenberg; Schrader and Fenner, 1976, pl. 6, figs. 1, 2 and 4 (Pl. 2, Fig. 19)

Hemiaulus sp. cf. H. incisus Hajós, 1976, p. 829, pl. 23, figs. 4-9

Hemiaulus sp. (pyxiloides form), Schrader and Fenner, 1976, p. 984, pl. 10, figs. 1-3 (Pl. 4, Figs. 7, 13-14)

Ikebea tenuis (Brun) Akiba, 1986, p. 439, pl. 19, figs. 1-5 = Goniothecium tenue Brun (Pl. 6, Figs. 9, 19-20)

Kisseleviella carina Sheshukova-Poretzkaya; Akiba, 1986, pl. 19, figs. 17-18; Akiba and Yanagisawa, 1986, p. 494, pl. 36, figs. 1-13; pl. 37, figs. 1-9 (Pl. 6, Figs. 16, 17)

Kisseleviella ezoensis Akiba, 1986, p. 440, pl. 19, figs. 13-16 (Pl. 6, Figs. 10-12)

Kisselviella magnaareolata Akiba et Yanagisawa, 1986, p. 495, pl. 38, figs. 10-18 (Pl. 6, Figs. 18, 21)

Kozloviella minor Jousé, 1973, p. 352, pl. 4, fig. 18 (Pl. 1, Figs. 13, 20)

Lisitzinia ornata Jousé; Fenner, 1985, p. 734, pl. 10, fig. 11 (Pl. 1, Figs. 15-18)

Lisitzinia ornata f. pentagona Harwood, 1986, p. 86, pl. 2, figs. $5,9=L$. quinquelobata Pushkar, 1987, p. 67, pl. 2, fig. 8 (Pl. 1, Fig. 19)

Mediaria splendida Sheshukova-Poretzkaya; Schrader, 1973, pl. 3, figs. 14, 15 (P1. 6, Figs. 13, 14)

Melosira architecturalis Brun; Schrader and Fenner, 1976, p. 989, pl. 14, fig. 13; pl. 29, figs. 7-8; pl. 35, figs. $1-4=$ Cyclotella hannae Kanaya (PI. 2, Fig. 2) 
Nitzschia challengeri Schrader; Akiba, 1986, pl. 24, fig. 12(?) (PI. 8, Figs. 1,2 )

Nitzschia sp. aff. N. challengeri Schrader (PI. 8, Figs. 3-8)

Remarks. Distinguished by asymmetrical apices and more convex (transpically) margins. It is also similar to $N$. januaria Schrader 1976, although it differs in its asymmetrical apices and much older age distribution.

Nitzschia maleinterpretaria Schrader; Barron, 1983, pl, 5, figs. 7, 8; Yanagisawa and Akiba, 1990, p. 226, pl. 1, figs. 1-4; pl. 9, figs. 1-7 (Pl. 8, Figs. 2-8)

Paralia sulcata (Ehrenberg) Cleve = Melosira sulcata (Ehrenberg) Kützing; Schrader, 1973, pl. 20, fig. 9 (Pl. 2, Fig. 1)

Pseudodimerogramma elegans Schrader in Schrader and Fenner, 1976, p. 993. pl. 3, fig. 14 (Pl. 6, Fig. 8)

Pseudotriceratium radiosoreticulatum Grunow; Fenner, 1985, pl. 12, fig. 11 $=P$. aff. chenevier $i$ sensu Schrader and Fenner, 1976, pl. 26, figs. 6, 8-9; pl. 27, figs. 4, 13 (Pl. 4, Figs. 11, 12)

Pyxilla spp. (PI. 4, Figs. 6, 15, 17)

Remarks. Probably includes $P$. reticulata Grove et Sturt and $P$. gracilis Tempère et Forti.

Raphidodiscus marylandicus Christian; Schrader and Fenner, 1976, pl. 7, fig. 16; Barron, 1983, p. 512, pl. 5, fig. 14 (Pl. 1, Fig. 11)

Rhizosolenia hotaense Akiba, 1980, p. 10, pl. 4, figs. 56, 57 (Pl. 4, Figs. 5, 16) Remarks. Akiba (1980) notes that $R$. hotaense possesses a larger and more slender valve than $R$. norwegica, and that the valve's maximum diameter is more toward the apex than it is in $R$. norwegica.

Rhizosolenia norwegica Schrader in Schrader and Fenner, 1976, p. 996, pl. 9 . figs. 4, 10 (PI. 4, Figs. 3-4)

Rocella gelida (Mann) Bukry; Gombos, 1983, pl. 1, figs. 1-6; Barron, 1985a, pl. 12, fig. 16 (Pl. 1, Figs. 3, 7)

Rocella gelida var. schraderi (Bukry) Barron; Barron, 1985a, pl. 12, fig. $15=$ R. schraderi Bukry; Gombos, 1983, pl. 1, figs. 13-16 (Pl. 1, Figs, 4, 8)

Remarks. The scarcity of this variety in Hole $884 \mathrm{~B}$, compared with its more common abundance in tropical sediment, suggests that it preferred warmer waters.

Rocella praenitida (Fenner) Fenner in Kim and Barron, 1986, p. 177, pl. 4. fig. 3 = Coscinodiscus praenitidus Fenner in Schrader and Fenner, 1976, p. 972 , pl. 14 , figs. $7,8,9,12$; pl. 27 , fig. 8 ; pl. 35 , fig. 5

Rocella semigelida Gombos, 1983, p. 796, pl. 2, figs. 1-12 (PI. 1, Figs. 5-6, $9-10,12)$

Remarks. The occurrence of $R$. semigelida in Hole 884B is the first reported occurrence of this taxon in the Pacific Ocean; previous reports are from the South Atlantic (Gombos, 1983) and the southern Indian Ocean (Harwood and Maruyama, 1992).

Rocella vigilans Fenner; Gombos, 1983, pl. 1, figs. 7-12; Fenner, 1985, pl. 7. figs. 14, 15 (Pl. 1, Figs. 1, 2)
Rouxia sp. cf. R. granda Schrader in Schrader and Fenner, 1976, p. 997, pl. 7. fig. 17 (Pl. 6, Figs. 3, 4)

Remarks. Only observed as fragments.

Rouxia isopolica Schrader, 1976, p. 635, pl. 5, figs. 9, 14-15, 20 (Pl. 6, Figs. $1,2)$

Rouxia naviculoides Schrader, 1973, p. 710, pl. 3, figs. 27-32 (PI. 6, Fig. 5)

Rouxia obesa Schrader in Schrader and Fenner, 1976, p. 997, pl. 24, figs. 5, 6 (Pl. 6, Figs. 6, 7)

Sceptroneis spp. (tenue-pesplanus group) (Pl. 4, Figs. 8,9)

Remarks. Fragments of $S$. pesplanus Fenner et Schrader in Schrader and Fenner, 1976, p. 998, pls. 22 (figs. 30-31) and 25 (figs. 10-11); and S. tenue Schrader and Fenner, 1976, p. 999, pls. 3 (figs. 1-4), 24 (figs. 14-16), and 25 (figs. 12, 22, 24) are tabulated together.

Simonseniella interposita (Hajós) A. Gladenkov et Barron, comb. nov.

Basionym. Rhizosolenia interposita Hajós, 1976, p. 827, pl. 21, fig. 8

Remarks. If Sundström's (1986) publication of Proboscia in a Ph.D. dissertation is considered a valid publication, then this taxon might be cited as Proboscia praebarboi (Hajós) Jordan and Priddle.

Simonseniella praebarboi $($ Schrader) Fenner $=$ Rhizosolenia praebarboi Schrader, 1973, p. 709, pl. 24, figs. 1-3 (Pl. 4, Figs. 1, 2)

Remarks. If Sundström's (1986) publication of Proboscia in a Ph.D. dissertation is considered a valid publication, then this taxon might be cited as Proboscia praebarboi (Hajós) Jordan and Priddle.

Stellarima spp. (group) = Coscinodiscus symbolophorus Grunow; Akiba, 1986, pl. 2, fig. 1 (Pl. 9, Figs. 9, 10)

Remarks. S. microtrias Hasle et Sims, 1976, and S. stellaris Hasle and Sims, 1976, are not separated here.

Thalassionema nitzschioides Grunow; Schrader, 1973, pl. 23, figs. 2, 6, 8, 9, 10, 26, 29, 34 (Pl. 5, Figs. 11, 12)

Thalassionema nitzschioides var. parva Heiden in Heiden and Kolbe, 1928 , p. 564, pl. 35, fig. 118 (Pl. 5, Fig. 13)

Thalassiosira dubiosa Schrader in Schrader and Fenner, 1976, p. 1001, pl. 35 , figs. 4-6 (Pl. 2, Fig. 7a-b)

Thalassiosira fraga Schrader; Akiba, 1986, pl. 8, figs. 12-13 (Pl. 1, Figs. $14-15,18)$

Thalassiosira irregulata Schrader in Schrader and Fenner, 1976, p. 1001, pl. 20, figs. 10-12 (Pl. 2, Figs. 12, 13a-b)

Thalassiosira lusca Schrader in Schrader and Fenner, 1976, p. 1002, pl. 35 , figs. 1-3 (Pl. 1, Figs. 10, 11)

Thalassiosira mediaconvexa Schrader in Schrader and Fenner, 1976, p. 1002 , pl. 36, fig. 1 (PI. 2, Figs. 8, 16 [aff.])

Thalassiothrix longissima Cleve et Grunow; Akiba, 1986, p. 447, pl. 21, fig. 18 (Pl. 5, Fig. 28)

Yoshidaia divergensis Komura; Yanagisawa and Akiba, 1990, pl. 9, figs. 10-11 (Pl. 8, Fig. 27) 


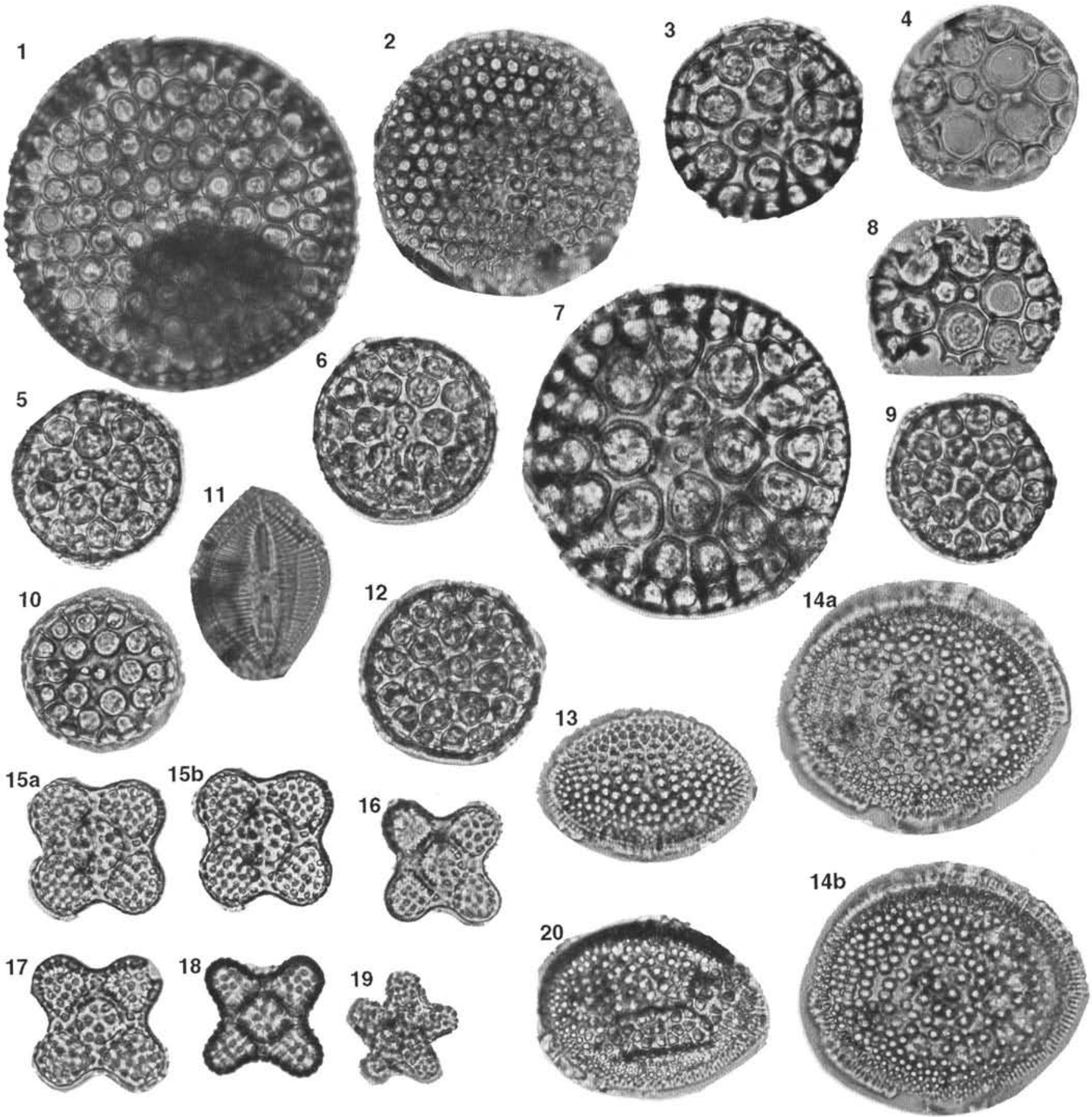

Plate 1. Magnification for all figures is 1000×. 1, 2. Rocella vigilans; (1) Sample 145-884B-69X-4, 25-26 cm; (2) Sample 145-884B-70X-CC. 3, 7. Rocella gelida; (3) Sample 145-884B-69X-2, 26-26 cm; (7) Sample 145-884B-69X-1, 25-26 cm. 4, 8. Rocella gelida var. schraderi, Sample 145-884B$71 \mathrm{X}-4,25-26 \mathrm{~cm} . \quad \mathbf{5 , 6 , 9 , 1 0 , 1 2}$. Rocella semigelida, Sample 145-884B-71X-4, 25-26 cm. 11. Raphidodiscus marylandicus, Sample 145-884B-66X-3, 25-26 cm. 13, 20. Kozloviella minor; (13) Sample 145-884B-70X-6, 25-26 cm; (20) Sample 145-884B-70X-CC. 14. Coscinodiscus lewisianus var. levis, Sample 145-884B-70X-6, 25-26 cm (a, b = different focuses of the same specimen). 15-18. Lisitzinia ornata; (15-17) Sample 145-884B-69X-3, 25-26 cm (15a-b = different focuses); (18) Sample 145-884B-69X-2, 25-26 cm. 19. Lisitzinia ornata f. pentagona, Sample 145-884B-69X-2, 25-26 cm. 

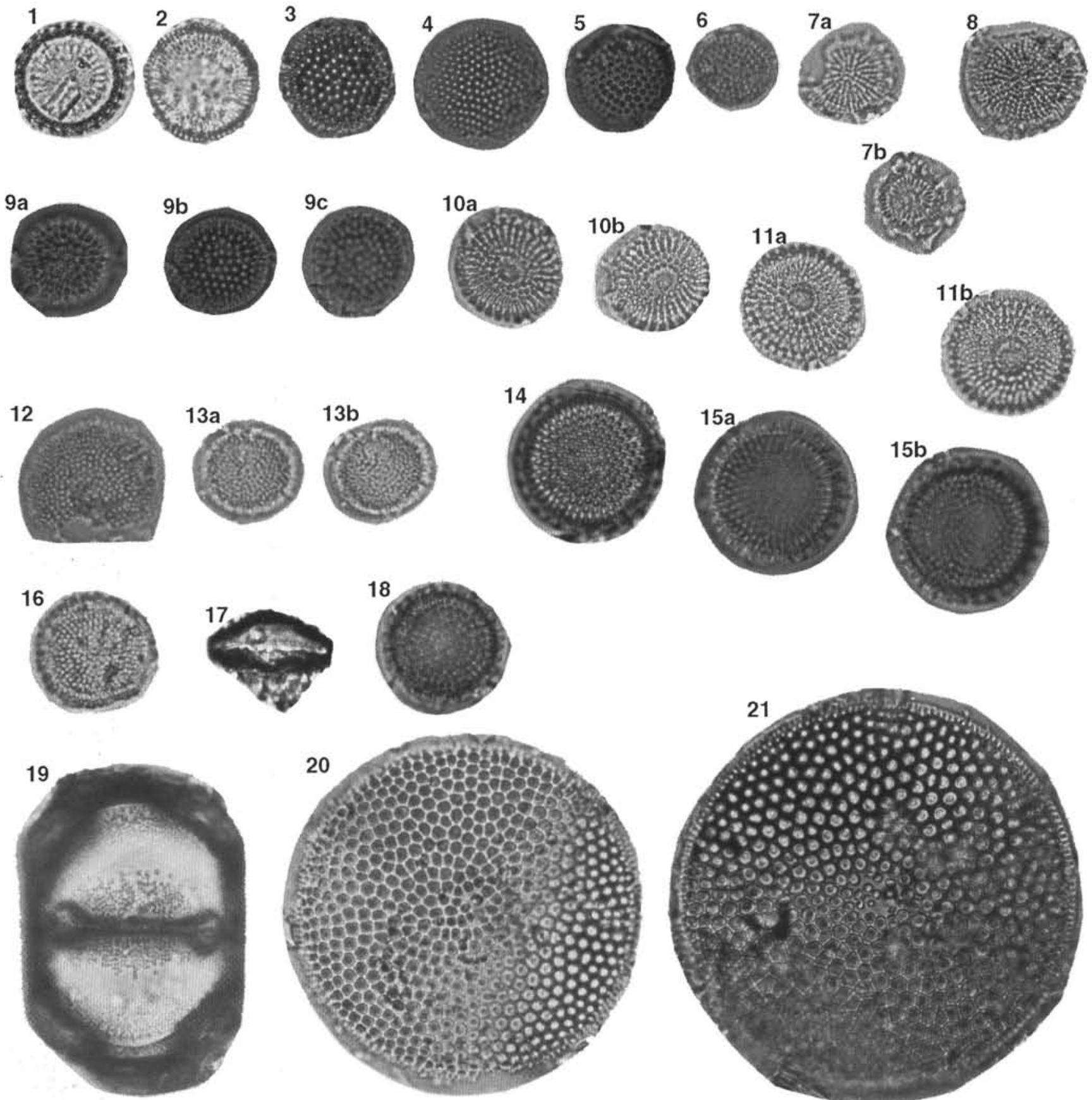

Plate 2. Magnification for all figures is 1000x. 1. Paralia sulcata, Sample 145-884B-69X-3,25-26 cm. 2. Melosira architecturalis, Sample 145-884B68X-CC. 3-6, 9. Thalassiosira praefraga sp. nov.; (3, 4) Sample 145-884B-66X-4, 25-26 cm; (5) Sample 145-884B-66X-5, 25-26 cm (a-c = different focuses); (6) Sample 145-884B-67X-CC; (9) holotype Sample 145-884B-66X-5, 25-26 cm (a-c = different focuses). 7. Thalassiosira dubiosa, Sample 145-884B-71X-6, 25-26 cm ( $\mathrm{a}, \mathrm{b}=$ different focuses). 8. Thalassiosira mediaconvexa, Sample 145-884B-69X-3, 25-26 cm. 10, 11. Thalassiosira lusca, Sample 145-884B-67X-7, 24-25 cm (a, b = different focuses). 12, 13. Thalassiosira irregulata; (12) Sample 145-884B-68X-3, 25-26 cm; (13) Sample 145-884B-67X-3, 24-25 cm ( $\mathrm{a}, \mathrm{b}=$ different focuses), 14, 15, 18. Thalassiosira fraga, Sample 145-884B-66X-3, 25-26 cm ( $15 \mathrm{a}, \mathrm{b}=$ different focuses). 16. Thalassiosira aff. mediaconvexa, Sample 145-884B-67X-3, 24-25 cm. 17. Chaetoceros spore, Sample 145-884B-69X-1, 25-26 cm. 19. Goniothecium odontella, Sample 145-884B-68X-6, 25-26 cm. 20. Azpeitia salisburyana, Sample 145-884B-67X-3, 24-25 cm. 21. Azpeitia praenodulifera, Sample 145-884B-66X-3, 25-26 cm. 

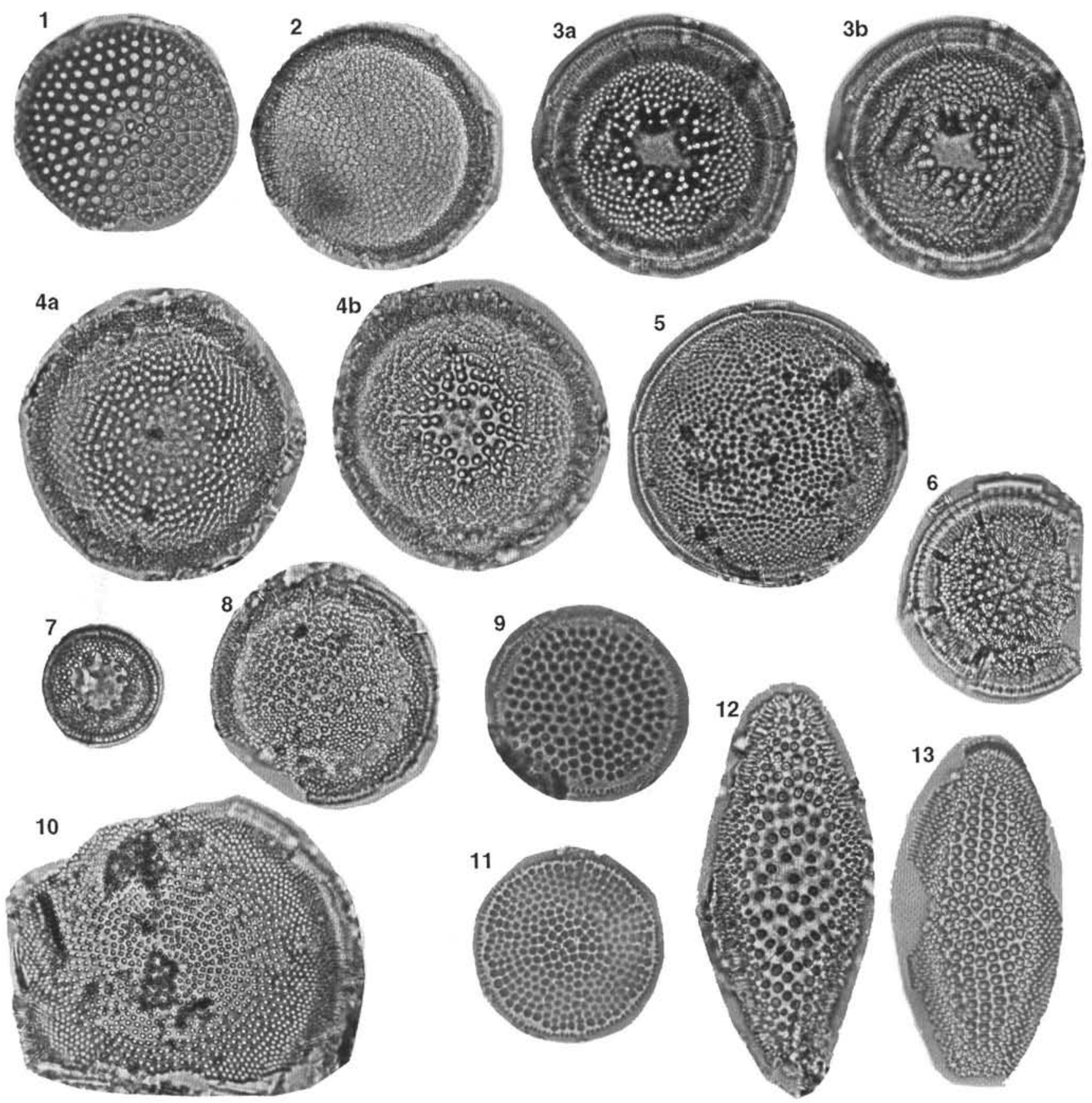

Plate 3. Magnification for all figures is $1000 \times$. 1. Azpeitia sp. aff. A. praenodulifera, Sample 145-884B-66X-3, 25-26 cm. 2-6. Cestodiscus kugleri; (2) Sample 145-884B-70X-CC; (3, 4) Sample 145-884B-71X-5, 25-26 cm (a, b = different focuses); (5) Sample 145-884B-69X-1, 25-26 cm; (6) Sample 145-884B-71X-4, 25-26 cm. 7. Cestodiscus kugleri?, Sample 145-884B-71X-4, 25-26 cm. 8, 10. Cestodiscus trochus; (8) Sample 145-884B-69X-1, 25-26 cm; (10) Sample 145-884B-70X-CC. 9, 11. Azpeitia tabularis, (9) Sample 145-884B-64X-4, 28-29 cm; (11) Sample 145-884B-67X-7, 24-25 cm. 12. Coscinodiscus rhombicus, Sample 145-884B-69X-1, 25-26. 13. Coscinodiscus lewisianus, Sample 145-884B-62X-CC. 

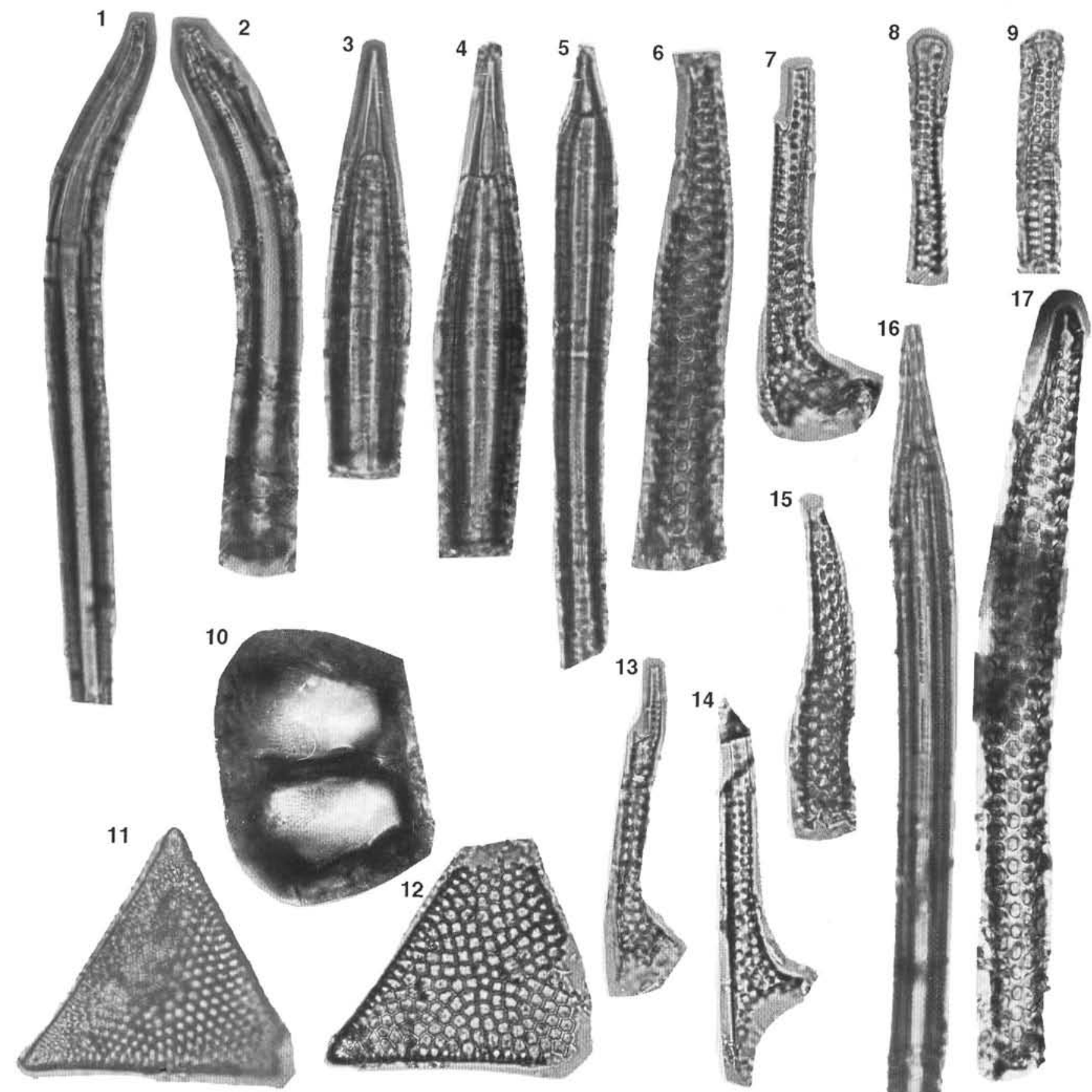

Plate 4. Magnification for all figures is $1000 \times$. 1, 2. Simonseniella praebarboi; (1) Sample 145-884B-64X-1, 25-26 cm; (2) Sample 145-884B-64X-3, $25-26 \mathrm{~cm}$. 3, 4. Rhizosolenia norwegica, Sample 145-884B-66X-3, 25-26 cm. 5, 16. Rhizosolenia hotaense; (5) Sample 145-884B-66X-3, 25-26 cm; (16) Sample 145-884B-66X-1, 25-26 cm. 6, 15, 17. Pyxilla spp.; (6) Sample 145-884B-68X-CC; (15) Sample 145-884B-71X-4, 25-26 cm; (17) Sample 145-884B-69X-1, 25-26 cm. 7, 13, 14. Hemiaulus sp. (pyxiloides); (7) Sample 145-884B-70X-6, 25-26 cm; (13) Sample 145-884B-70X-7, 25-26 cm; (14) Sample 145-884B-69X-2, 25-26 cm. 8,9. Sceptroneis tenue-pesplanus group; (8) Sample 145-884B-69X-3, 25-26 cm; (9) Sample 145-884B-70XCC. 10. Goniothecium odontella, Sample 145-884B-69X-1, 25-26 cm. 11, 12. Pseudotriceratium radiosoreticulatum; (11) Sample 145-884B-67X-7, 24-25 cm; (12) Sample 145-884B-70X-7, 25-26 cm. 

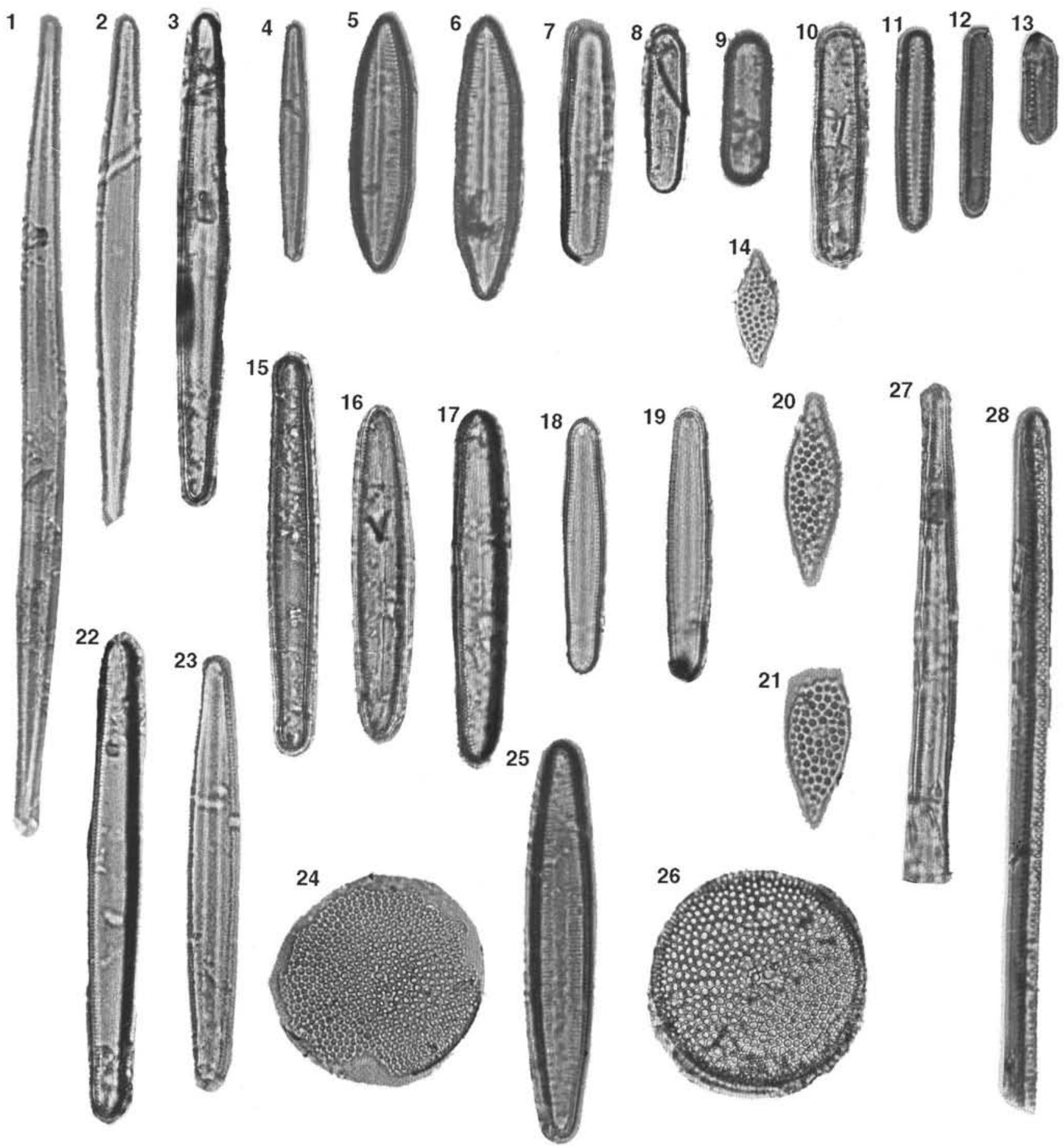

Plate 5. Magnification for all figures is $1000 \times$. 1, 2, 27. Cavitatus miocenicus, Sample 145-884B-70X-6, 25-26 cm. 3, 15, 18, 19, 22, 23. Cavitatus jouseanus; $(3,18,19)$ Sample 145-884B-70X-CC; (15) Sample 145-884B-69X-4, $25-26 \mathrm{~cm}$; (22) Sample 145-884B-69X-3, 25-26 cm; (23) Sample 145-884B-70X-7, 25-26 cm. 4. Cavitatus exiguus, Sample 145-884B-62X-4, 25-26 cm. 5, 6. Cavitatus lanceolatus, Sample 145-884B-62X-4, 25-26 cm. 7-10. Cavitatus rectus; (7) Sample 145-884B-70X-7, 25-26 cm; (8) Sample 145-884B-70X-CC; (9) Sample 145-884B-67X-7, 24-25 cm; (10) Sample 145-884B-69X-3, 25-26 cm. 11, 12. Thalassionema nitzschioides; (11) Sample 145-884B-64X-4, 28-29 cm; (12) Sample 145-884B-64X-5, 25-26 cm. 13. Thalassionema nitzschioides var. parva, Sample 145-884B-64X-4, 28-29 cm. 14, 20, 21. Cymatosira sp. aff. C. lorenziana; (14) Sample 145-884B70X-6, 25-26 cm; $(20,21)$ Sample 145-884B-70X-7, 25-26 cm. 16, 17, 25. Cavitatus linearis; $(16,17)$ Sample 145-884B-70X-6, 25-26 cm; (25) Sample 145-884B-66X-3, 25-26 cm. 24, 26. Azpeitia oligocenica; (24) Sample 145-884B-70X-7, 25-26 cm; (26) Sample 145-884B-70X-6, 25-26 cm. 28. Thalassiothrix longissima, Sample 145-884B-64X-3, 25-26 cm. 

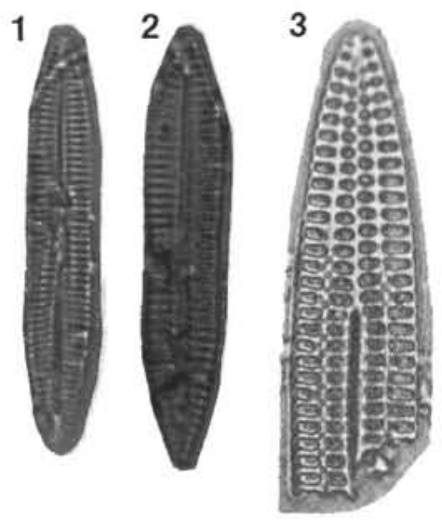

13
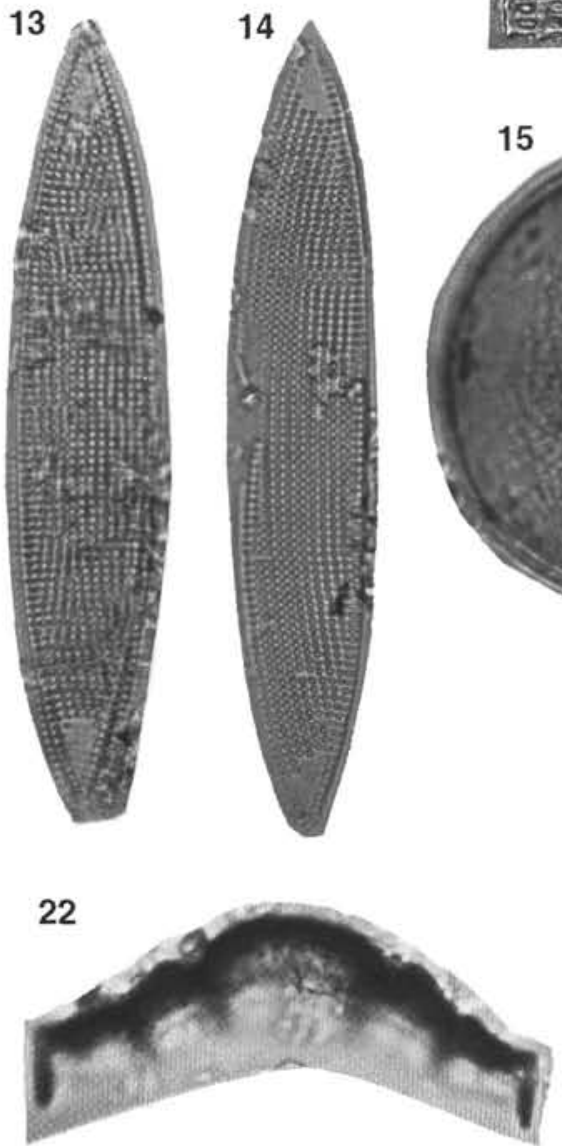
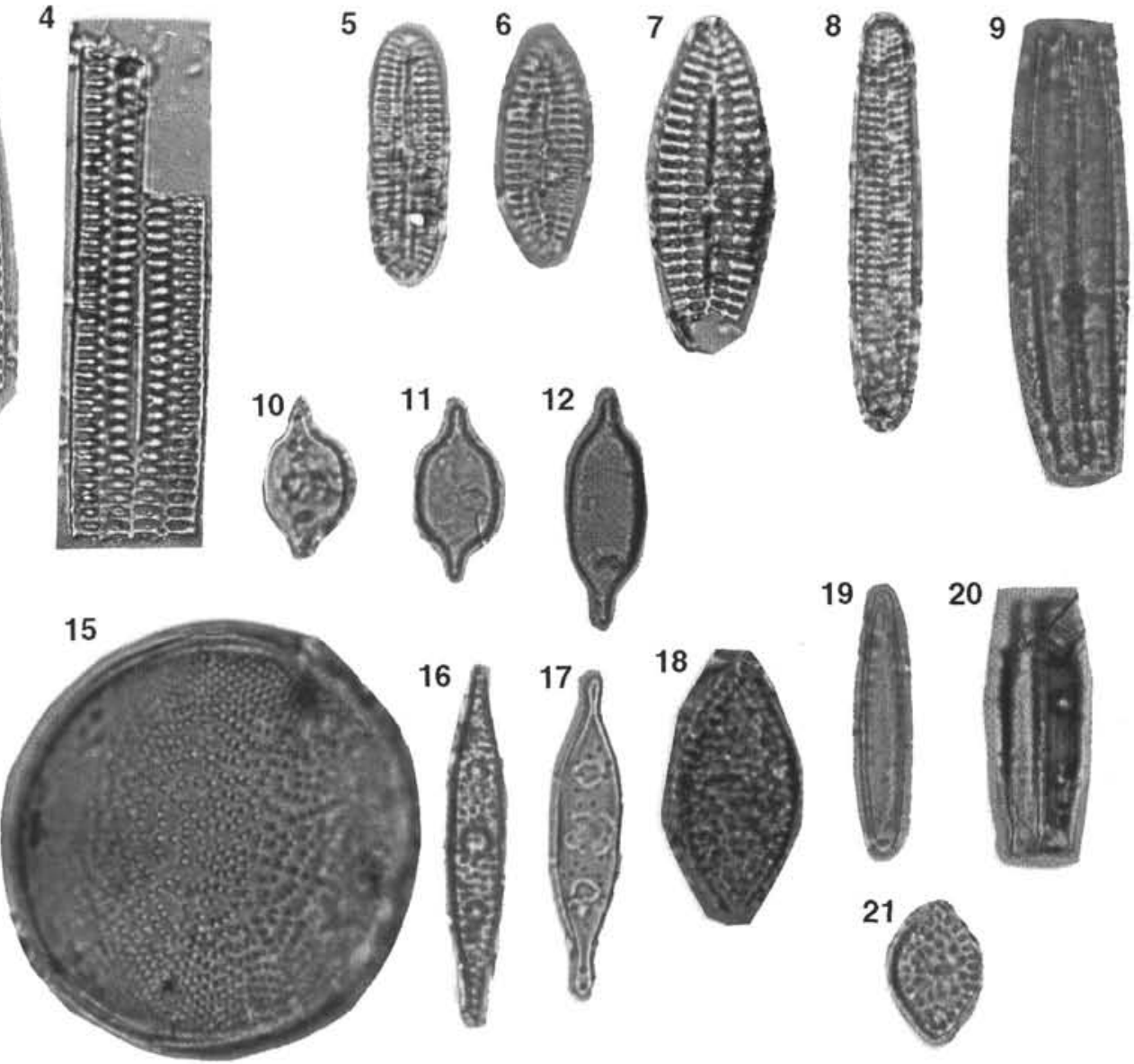

18
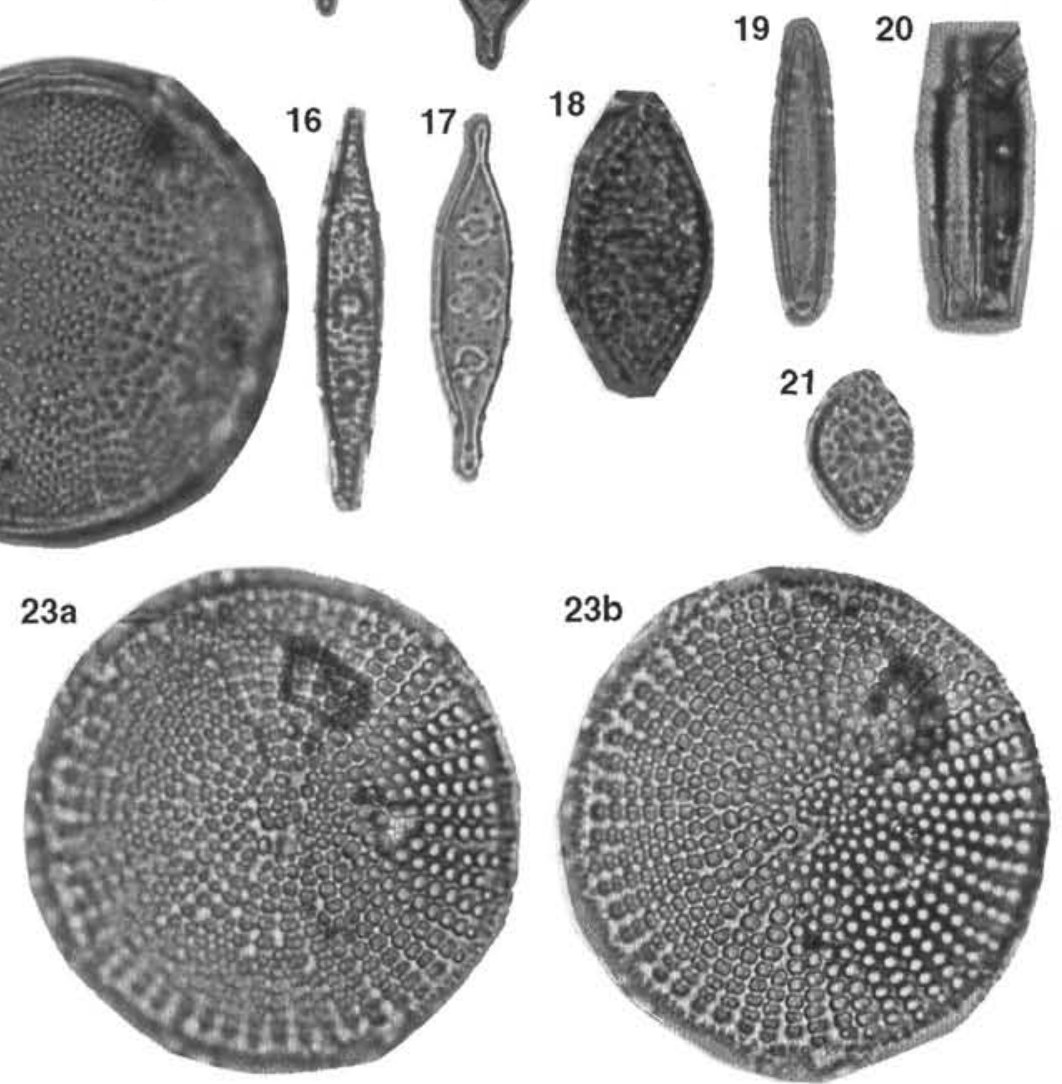

Plate 6. Magnification for all figures is $1000 \times$. 1, 2. Rouxia isopolica, Sample 145-884B-64X-5, 25-26 cm. 3, 4. Rouxia sp. cf. R. granda; (3) Sample 145-884B-67X-7, 24-25 cm; (4) Sample 145-884B-70X-6, 25-25 cm. 5. Rouxia naviculoides, Sample 145-884B-73X-CC. 6, 7. Rouxia obesa, (6) Sample 145-884B-67X-6, 24-25 cm; (7) Sample 145-884B-70X-CC. 8. Pseudodimerogramma elegans, Sample 145-884B-67X-4, 24-25 cm. 9, 19, 20. Ikebea tenuis; (9) Sample 145-884B-66X-6, 25-26 cm; (19) Sample 145-884B-67X-7, 24-25 cm; (20) Sample 145-884B-63X-CC. 10-12. Kisseleviella ezoensis; (10) Sample 145-884B-67X-3, 24-25 cm; (11) Sample 145-884B-66X-6, 25-26 cm; (12) Sample 145-884B-67X-5, 24-25 cm. 13, 14. Mediaria splendida, Sample 145-884B-63X-5, 25-26 cm. 15. Actinocyclus octonarius, Sample 145-884B-66X-3, 25-26 cm. 16, 17. Kisseleviella carina; (16) Sample 145-884B-67X-7, 24-25 cm; (17) Sample 145-884B-67X-6, 24-25 cm. 18,21. Kisseleviella magnaareolata, (18) Sample 145-884B-66X-4, 25-26 cm; (21) Sample 145-884B-67X-7, 24-25 cm. 22. Goniothecium decoratum, Sample 145-884B-67X-7, $24-25 \mathrm{~cm}$. 23. Azpeitia biradiata, Sample 145-884B-67X-3, 24-25 cm (a, b = different focuses). 


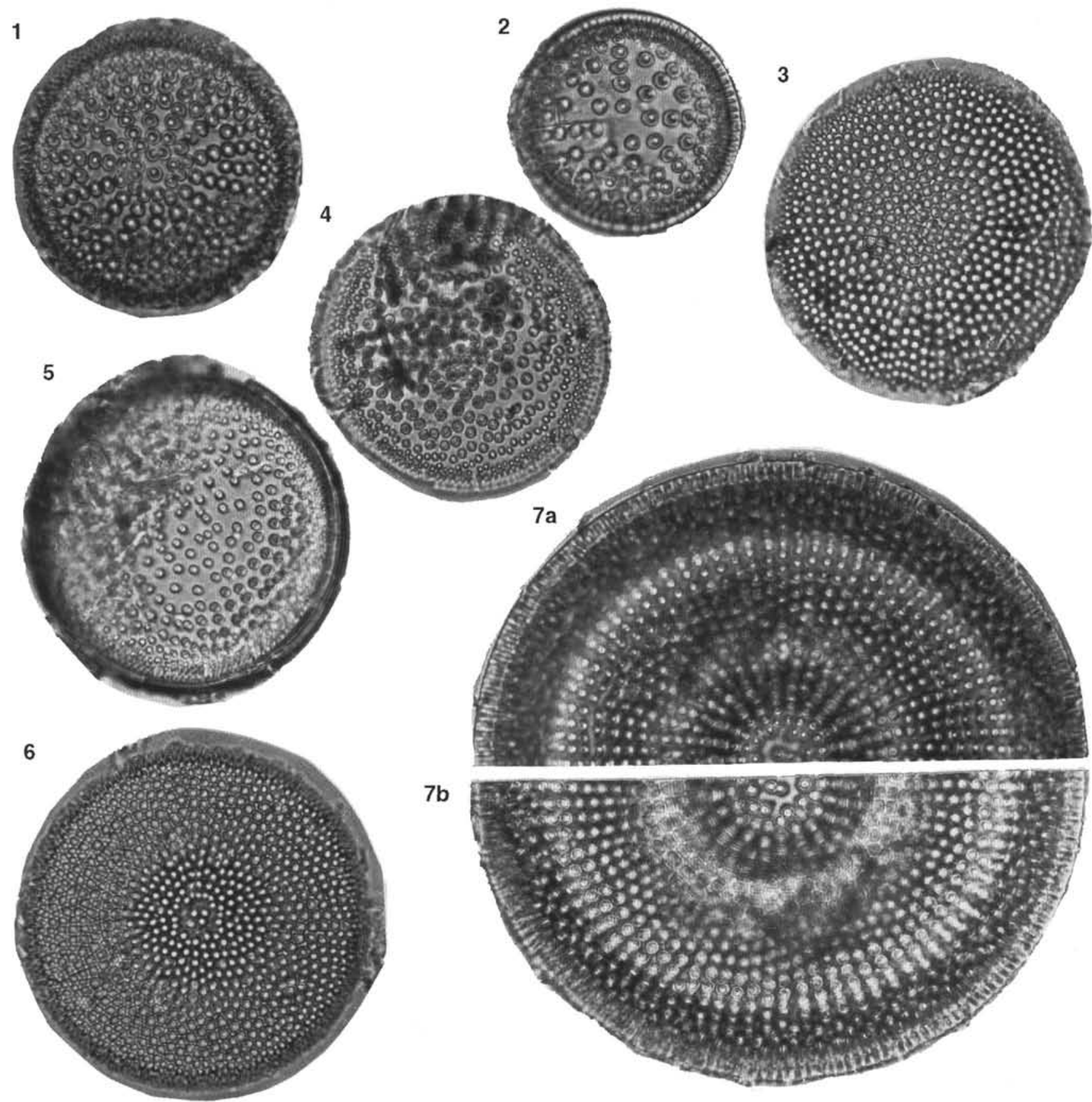

Plate 7. Magnification for all figures is 1000X. 1, 2. Actinocyclus ingens; (1) Sample 145-884B-63X-2, 25-26 cm; (2) Sample 145-884B-63X-4, 25-26 cm. 3, 6. Actinocyclus tsugaruensis, Sample 145-884B-64X-6, 25-26 cm. 4, 5. Actinocyclus sp. (ohotensis-ingens form), Sample 145-884B-64X-6, $25-26 \mathrm{~cm}$. 7. Actinocyclus ingens var. nodus, Sample 145-884B-62X-CC ( $\mathrm{a}, \mathrm{b}=$ different focuses). 

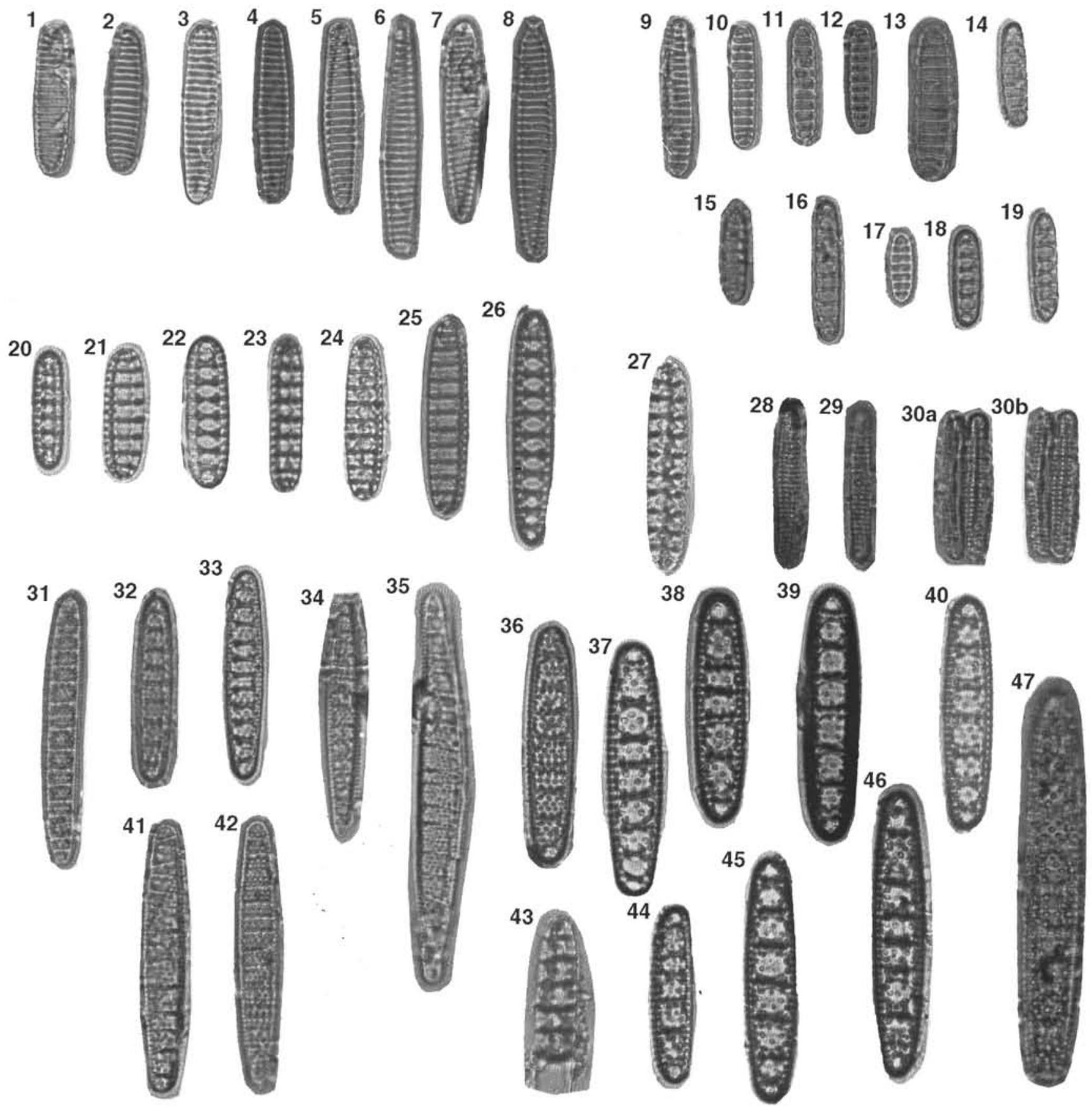

Plate 8. Magnification for all figures is $1000 \times$. 1, 2. Nitzschia challengeri, Sample 145-884B-63X-5, 25-26 cm. 3-8. Nitzschia sp. aff. N. challengeri, Sample 145-884B-63X-5, 25-26 cm. 9-19. Denticulopsis praelauta; (9-13, 16, 18, 19) Sample 145-884B-63X-5, 25-26 cm; (14, 15, 17) Sample 145-884B-63X-CC. 20-26. Denticulopsis lauta, Sample 145-884B-62X-6, 25-26 cm. 27. Yoshidaia divergens, Sample 145-884B-62X-6, 25-26 cm. 28-30. Nitzschia maleinterpretaria, Sample 145-884B-66X-2, 25-26 cm (30a-b = different focuses). 31-33, 36, 41, 42. Crucidenticula sawamurae; (31) Sample 145-884B-64X-6, 25-26 cm; (32, 33) Sample 145-884B-64X-CC; $(36,42)$ Sample 145-884B-64X-5, 25-26 cm; (41) Sample 145-884B-64X-3, 25-26 cm. 34, 35. Crucidenticula ikebei, Sample 145-884B-64X-3, 25-26 cm. 37-40, 44-47. Crucidenticula kanayae; (37-40, 44) Sample 145-884B64X-3, 25-26 cm; $(45,46)$ Sample 145-884B-64X-4, 28-29 cm; (47) Sample 145-884B-64X-2, 25-26 cm. 43. Denticulopsis hyalina, Sample 145-884B$62 \mathrm{X}-4,25-26 \mathrm{~cm}$. 


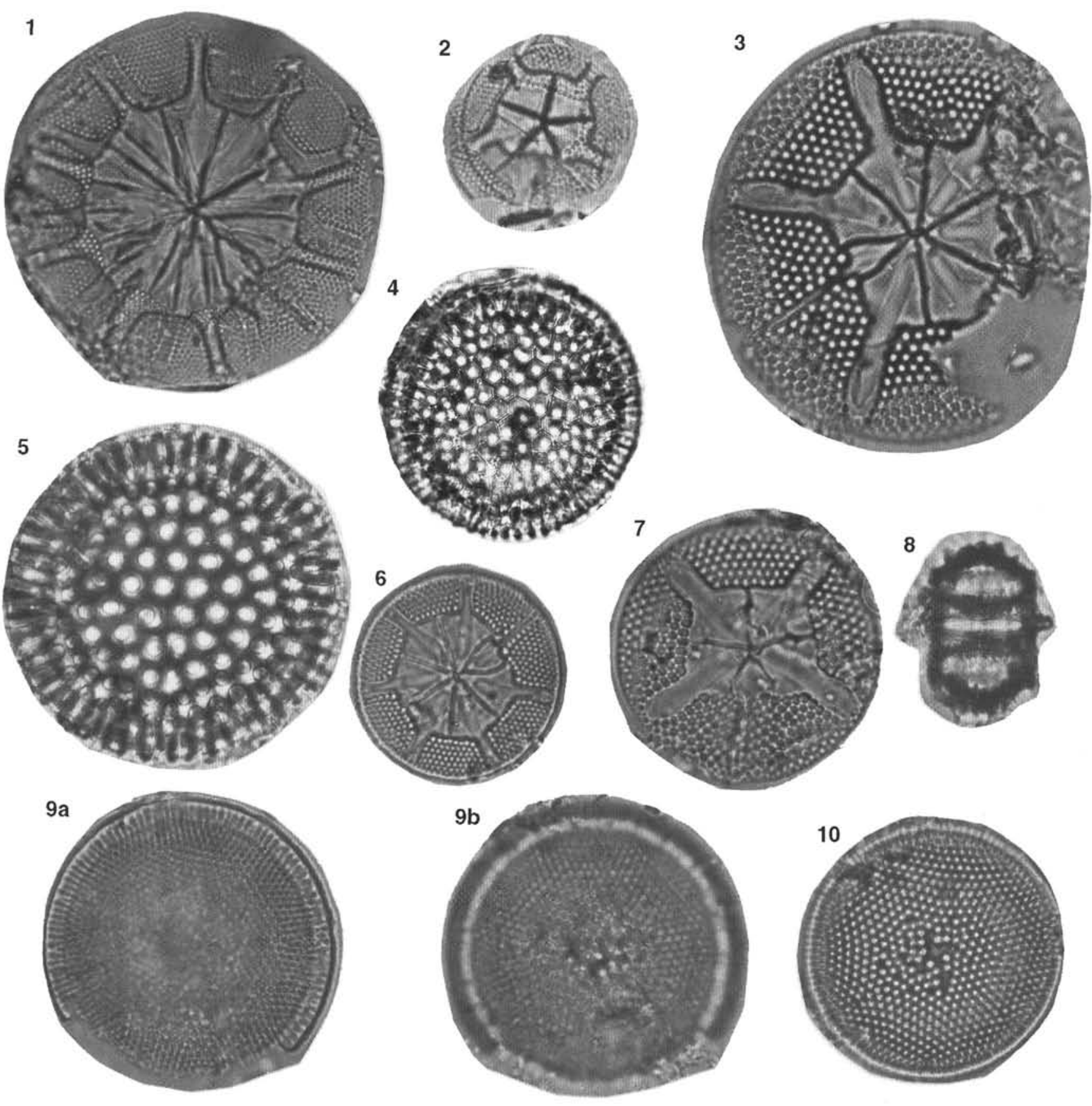

Plate 9. Magnification for all figures is $1000 \times$. 1, 6. Asteromphalus sp. aff. A. oligocenicus, Sample 145-884B-64X-5, 25-26 cm. 2. Asteromphalus sp. cf. A. darwinii, Sample 145-884B-63X-CC. 3,7. Asteromphalus sp. aff. A. robustus-symmetricus, Sample 145-884B-64X-5, 25-26 cm. 4,5. Coscinodiscus marginatus; (4) Sample 145-884B-69X-2, 25-26 cm; (5) Sample 145-884B-66X-2, 25-26 cm. 8. Chaetoceros spore, Sample 145-884B-66X-6, 25-26 cm. 9, 10. Stellarima group; (9) Sample 145-884B-66X-6, 25-26 cm (a, b = different focuses); (10) Sample 145-884B-66X-5, 25-26 cm. 